\title{
Uncertainties in assessing the environmental impact of amine emissions from a $\mathrm{CO}_{2}$ capture plant
}

\author{
M. Karl ${ }^{1}$, N. Castell ${ }^{1}$, D. Simpson ${ }^{3,4}$, S. Solberg ${ }^{1}$, J. Starrfelt ${ }^{2}$, T. Svendby ${ }^{1}$, S.-E. Walker ${ }^{1}$, and R. F. Wright ${ }^{2}$ \\ ${ }^{1}$ Norwegian Institute for Air Research, NILU, Kjeller, Norway \\ ${ }^{2}$ Norwegian Institute for Water Research, NIVA, Gaustadalléen 21, 0349 Oslo, Norway \\ ${ }^{3}$ EMEP MSC-W, Norwegian Meteorological Institute, Oslo, Norway \\ ${ }^{4}$ Dept. Earth and Space Sciences, Chalmers Univ. Technology, Gothenburg, Sweden
}

Correspondence to: M. Karl (mka@nilu.no)

Received: 17 December 2013 - Published in Atmos. Chem. Phys. Discuss.: 31 March 2014

Revised: 2 July 2014 - Accepted: 13 July 2014 - Published: 25 August 2014

\begin{abstract}
In this study, a new model framework that couples the atmospheric chemistry transport model system Weather Research and Forecasting-European Monitoring and Evaluation Programme (WRF-EMEP) and the multimedia fugacity level III model was used to assess the environmental impact of in-air amine emissions from post-combustion carbon dioxide capture. The modelling framework was applied to a typical carbon capture plant artificially placed at Mongstad, on the west coast of Norway. The study region is characterized by high precipitation amounts, relatively few sunshine hours, predominantly westerly winds from the North Atlantic and complex topography. Mongstad can be considered as moderately polluted due to refinery activities. WRF-EMEP enables a detailed treatment of amine chemistry in addition to atmospheric transport and deposition. Deposition fluxes of WRF-EMEP simulations were used as input to the fugacity model in order to derive concentrations of nitramines and nitrosamine in lake water. Predicted concentrations of nitramines and nitrosamines in ground-level air and drinking water were found to be highly sensitive to the description of amine chemistry, especially of the night-time chemistry with the nitrate $\left(\mathrm{NO}_{3}\right)$ radical. Sensitivity analysis of the fugacity model indicates that catchment characteristics and chemical degradation rates in soil and water are among the important factors controlling the fate of these compounds in lake water. The study shows that realistic emission of commonly used amines result in levels of the sum of nitrosamines and nitramines in ground-level air $\left(0.6-10 \mathrm{pg} \mathrm{m}^{-3}\right)$ and drinking water $\left(0.04-0.25 \mathrm{ng} \mathrm{L}^{-1}\right)$ below the current safety guideline for human health that is enforced by the Norwegian Environ-
\end{abstract}

ment Agency. The modelling framework developed in this study can be used to evaluate possible environmental impacts of emissions of amines from post-combustion capture in other regions of the world.

\section{Introduction}

Post-combustion carbon dioxide capture encompasses the removal of $\mathrm{CO}_{2}$ from the flue gas of a combustion process, mainly in gas-fired or coal-fired power plants. The most widely used chemical absorption technology for postcombustion on an industrial scale is scrubbing with an aqueous solution of monoethanolamine (MEA, 2-aminoethanol) as a solvent (Rochelle, 2009). In this method, MEA absorbs $\mathrm{CO}_{2}$ through chemical reaction in the absorber column. The use of amine-based solvents result in the emission of volatile organic compounds (VOCs) and ammonia $\left(\mathrm{NH}_{3}\right)$ into the air due to the degradation of the solvent (Strazisar et al., 2003) in the $\mathrm{CO}_{2}$ capture plant $(\mathrm{CCP})$. The $\mathrm{CCP}$ will release amines as gases and liquids to the air due to volatilization losses during the absorption process. Estimated emissions of MEA from post-combustion capture are between 0.3 and $0.8 \mathrm{~kg}$ MEA per tonne $\mathrm{CO}_{2}$ captured without water wash (Goff and Rochelle, 2004). Based on concentrations of MEA in the exhaust gas of 1-4 ppmv (Rao and Rubin, 2002), MEA emissions for a full-scale $\mathrm{CCP}$ that captures $1 \mathrm{Mt} \mathrm{CO}_{2}$ per year, are expected to range from 40000 to $160000 \mathrm{~kg}$ per year. Recent advances in emission control at CCPs may reduce solvent emissions. 
A potential concern for public health is the formation of nitrosamines, nitramines (i.e. N-nitro alkylamines and N-nitro alkanolamines), and amides that are products of the reaction of amines and atmospheric oxidants involving nitrogen oxides $\left(\mathrm{NO}_{\mathrm{x}}\right)$ under the influence of sunlight (Lee and Wexler, 2013; Nielsen et al., 2012b; Angove et al., 2012; Pitts et al., 1978). Reactions of amines with the atmospheric nitrate $\left(\mathrm{NO}_{3}\right)$ radical could be important during night-time (Nielsen et al., 2012b) and might lead to the formation of nitramines (Price, 2010). Unlike secondary and tertiary amines, the primary amine MEA does not form a stable nitrosamine in air (Nielsen et al., 2011; Karl et al., 2012). However, the formation of the nitramine of MEA, 2-nitro aminoethanol in the photo-oxidation of MEA has been confirmed (Nielsen et al., 2011; Karl et al., 2012). Richardson et al. (2007) have reviewed the occurrence and carcinogenicity of nitrosamines and nitramines. Nitrosamines are of particular concern, as they have been found to cause tumour formation for approximately $90 \%$ of 300 nitrosamines tested in laboratory animals and bioassays (Låg et al., 2011). Nitramines are also presumed to be carcinogenic, although there are little data available (Låg et al., 2011; Richardson et al., 2007). The possible formation of nitrosamines and nitramines in the plume from post-combustion $\mathrm{CO}_{2}$ capture systems employing amine-based solvents is the main risk for human health and environment, with implications for the design and implementation of this essential technology for mitigating climate change.

The foremost environmental concern associated with amine-based $\mathrm{CO}_{2}$ capture is the potential risk of nitrosamines in drinking water supplies. Different regulations for nitrosamine and nitramines have been enforced in North America and Europe. The State of California (California EPA, 2006) has an action level of $10 \mathrm{ng} \mathrm{L}^{-1}$ for $\mathrm{N}$ nitrosodimethylamine (NDMA). NDMA is currently not regulated in the United States in drinking water, but has been included in the proposed Unregulated Contaminants Monitoring Rule (UCMR-2; http://water.epa.gov/lawsregs/rulesregs/ sdwa/ucmr/ucmr2/). The US EPA has set a level of $7 \mathrm{ng} \mathrm{L}^{-1}$ NDMA in drinking water, representing a $10^{-6}$ risk for cancer. Canada does not regulate NDMA nationally, but Ontario has established a drinking water quality standard of $9 \mathrm{ng} \mathrm{L}^{-1}$ for NDMA. Due to the limited toxicity data on nitramines, the Norwegian Institute for Public Health decided to use the NDMA risk estimate for the total concentration of nitrosamines and nitramines in drinking water (Låg et al., 2011). The Norwegian Environment Agency (Miljødirektoratet) has directly addressed nitrosamines and nitramines related to amine scrubbing, restricting environmental levels of total nitrosamine and nitramine to $0.3 \mathrm{ng} \mathrm{m}^{-3}$ in air and $4 \mathrm{ng} \mathrm{L}^{-1}$ in water. The emission permit for the $\mathrm{CO}_{2}$ Technology Centre Mongstad (TCM) in Norway (de Koeijer et al., 2013) must adhere to these safety limits (Norwegian Climate and Pollution Agency, 2011).
Nitrosamines and nitramines may be formed in the atmosphere after the emission of precursor amines, but in addition they might also occur in the CCP and be emitted directly into the air from post-combustion (Reynolds et al., 2012). In wash water samples of a pilot plant, concentrations of $0.73 \mu \mathrm{M}$ total N-nitrosamines were found, requiring a 25000 -fold reduction between the wash water unit and downwind drinking water supplies in order to meet the permit limits of the Norwegian Environment Agency (Dai et al., 2012). Due to the lack of publicly available data for full-scale $\mathrm{CO}_{2}$ capture, we have not included direct emission of nitrosamines in our assessment.

While Gaussian-type dispersion models can provide accurate predictions of location and movement of the plume on the local scale, the description of air chemistry in the gas phase and aqueous phase leading to the transformation of reactive compounds is usually highly parameterized or based on semi-empirical schemes for photochemistry (Holmes and Morawska, 2006; Owen et al., 2000). Therefore, we utilized the new framework Weather Research and ForecastingEuropean Monitoring and Evaluation Programme (WRFEMEP), capable of treating specific air chemistry in addition to atmospheric transport by advection and diffusion. WRF-EMEP is a model system where the meteorological data is generated with the Weather Research and Forecast (WRF) model (Skamarock and Klemp, 2008) and the dispersion and air chemistry is solved with the EMEP model (Simpson et al., 2012). WRF-EMEP was coupled to a multimedia fugacity level III model to simulate annual average concentrations of nitrosamines and nitramines in the water compartment in an evaluative environment.

Karl et al. (2011) made a preliminary evaluation of the impacts of MEA emissions from a hypothetical CCP capturing $1 \mathrm{Mt}$ of $\mathrm{CO}_{2}$ per year. The evaluation considered air quality, drinking water, and aquatic ecosystems (Karl et al., 2011). However, the uncertainty associated with several of the model parameters and processes affected the results of this assessment; these included branching ratios and rate constants of the amine photo-oxidation scheme, the vertical emission profile, dry and wet deposition, and degradation rates in soil and water.

The goal of the sensitivity analysis presented in this paper is to identify the parameters and processes to which the simulation result, i.e. surface air concentration and total deposition flux of the sum of nitramines and nitrosamines, is most sensitive. In the present sensitivity analysis, a fictive $\mathrm{CCP}$ with generic emissions of amines and $\mathrm{NO}_{\mathrm{x}}$ was placed at the location of Mongstad, Norway. Emissions from the CCP were set to $40000 \mathrm{~kg}$ per year MEA and $5000 \mathrm{~kg}$ per year diethylamine (DEYA) in all simulations with the WRFEMEP system, consistent with the amine emissions applied in the study by Karl et al. (2011). The MEA emission amount is a factor of 10-60 higher than in the recent health risk study for the existing TCM facility at Mongstad (de Koeijer et al., 2013). We explicitly allow for the degradation of toxic 
compounds during transport in air, water, and soil, in order to make the assessment more realistic. We also estimate the uncertainties of predicted concentrations of toxic products in ground-level air and drinking water related to generic amine emissions from a CCP using a range of possible parameterizations in the coupled modelling framework.

\section{Methodology}

\subsection{Model framework}

Emission dispersion simulations were performed for a baseline case and several modified cases to estimate the uncertainties due to variations in single parameters. Annual average concentrations of nitrosamines and nitramines in the air at ground level and in lake water potentially used as a drinking water source were calculated in a $200 \mathrm{~km} \times 200 \mathrm{~km}$ domain with Mongstad in the centre. Mongstad $\left(60^{\circ} 48^{\prime} 17^{\prime \prime} \mathrm{N}\right.$, $\left.5^{\circ} 01^{\prime} 50^{\prime \prime} \mathrm{E}\right)$, Norway, is located approximately $60 \mathrm{~km}$ north of Bergen. Mongstad is situated at the coastline, only a few meters a.s.1., in the Fensfjorden-Austfjorden which aligns roughly from the SE to NW, with steeper terrain and higher hills/mountains on the north side (see topographic map in Fig. 1). The region is influenced by strong westerly winds from the North Atlantic for most of the year. To the east, the region is surrounded by a chain of hills and mountains up to $600 \mathrm{~m}$ in elevation.

Concentrations calculated by the WRF-EMEP model system were compared to the recommended air and drinking water quality criteria set by the Norwegian Environment Agency. The methodology outlined in the following can be transferred to other world regions and locations where the installation of a CCP is planned. The emission dispersion simulations included the following processes:

1. Emission of amines and $\mathrm{NO}_{\mathrm{x}}$ from the $\mathrm{CCP}$, represented as a point source (Sect. 2.4).

2. Atmospheric gas-phase chemistry of amines, covering oxidation of amines by hydroxyl $(\mathrm{OH})$ radicals and the photolysis of nitrosamines by sunlight (Sect. 2.5).

3. Partitioning of amines, nitrosamines, and nitramines to the aqueous phase of clouds (Sect. 2.6).

4. Dry and wet deposition of amines, nitrosamines, and nitramines (Sect. 2.6).

5. Fate of nitrosamines and nitramines in soil, transport by run-off to surface waters, and degradation in surface waters. The result was simulation of mean concentrations of nitrosamines and nitramines under steady-state conditions in a generic lake (Sect. 2.3)

Processes 1-4 were implemented in the atmospheric dispersion model, the WRF-EMEP model system (Sect. 2.2). Process 5 was treated by a fugacity level III model (Sect. 2.3) which uses simulated wet plus dry deposition of compounds from the atmospheric dispersion model as input (Fig. 2).

Specific input data to the EMEP model includes (1) dimensions and characteristics of the CCP point source (stack data); (2) emission data per compound; and (3) chemical parameters of the amine photo-oxidation scheme. The chemical data were used to set up the amine chemistry in the EMEP model (Sect. 2.5) and the emission data were used to set up the CCP emission point source (Sect. 2.4). The nested WRFEMEP model system uses meteorological data predicted by the weather forecast model WRF as input to the EMEP model to calculate air concentrations at the surface (ground level), and dry and wet deposition of amines, nitrosamines, and nitramines. The deposition (dry and wet) flux of nitrosamines and nitramines is then used as input to the fugacity level III model (Sect. 2.3) which computes mean annual concentrations of nitrosamines and nitramines in the water compartment of a typical lake. Finally, the maximum yearly average ground-level air concentration and lake water concentration in the $40 \mathrm{~km} \times 40 \mathrm{~km}$ study grid (with Mongstad as centre) inside the inner domain are compared to the pre-defined safety limits, i.e. $0.3 \mathrm{ng} \mathrm{m}^{-3}$ in air and $4 \mathrm{ng} \mathrm{L}^{-1}$ in drinking water (Låg et al., 2011), respectively, for the sum of nitrosamines and nitramines.

\subsection{Description of WRF-EMEP model system}

The WRF-EMEP model system combines the WRF numerical weather prediction model (NWP) with the EMEP MSC$\mathrm{W}$ chemical transport model (CTM). This system, which is similar to the EMEP4UK setup (Vieno et al., 2009, 2010), was recently implemented and tested at the Norwegian Institute for Air Research (NILU) (Colette et al., 2011; Solberg and Svendby, 2012).

WRF-EMEP follows a nested procedure. It calculates concentrations first in the outer domain (extending from eastern North America to western Europe) with a $50 \mathrm{~km}$ horizontal resolution, then uses these as initial and boundary conditions for the intermediate domain (Scandinavia) with $10 \mathrm{~km}$ horizontal resolution, and finally uses the outcome from the intermediate domain as initial and boundary conditions for the inner domain (west coast of central Norway; $200 \mathrm{~km} \times 200 \mathrm{~km}$ ) with $2 \mathrm{~km}$ horizontal resolution. The meteorological data calculated by the WRF model are fed into the EMEP model which is then used to simulate the emission, transport (by advection and turbulent diffusion), photochemical reactions, and dry and wet deposition for each of these nests. Within the setup of this one-way nesting algorithm, any air mass that exits the inner domain and then re-enters will have lost the original influence of the inner domain. Atmospheric transport of amines, nitrosamines, and nitramines from the point source were not expected to significantly impact concentrations beyond the borders of the intermediate domain $(10 \mathrm{~km}$ resolution) during the 1 year calculations. Boundary and initial 


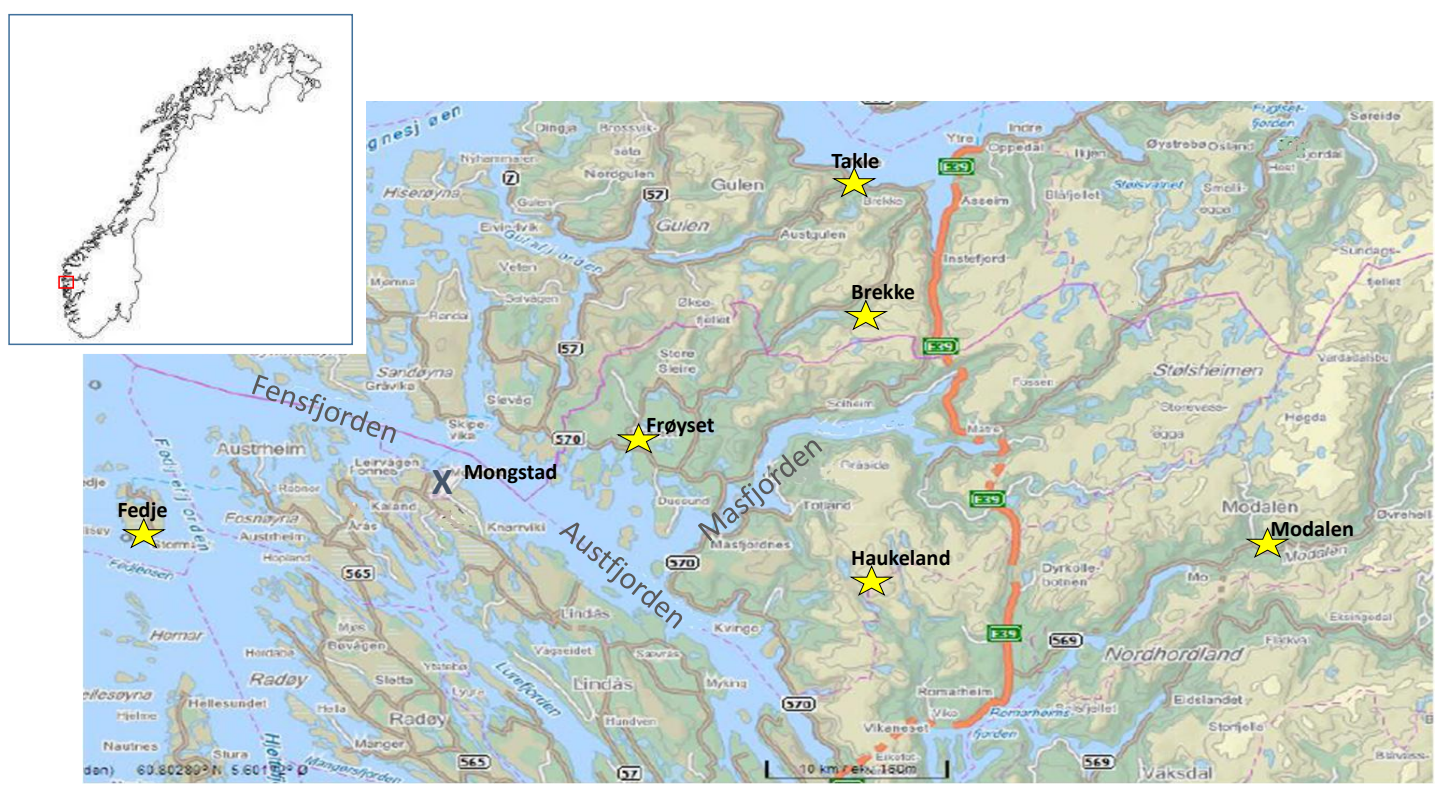

Figure 1. Topographic map of the study area. The industrial area at Mongstad is indicated by a blue X. Meteorological stations are shown by yellow stars. Inset in the upper left corner shows the location of the study area in Norway.

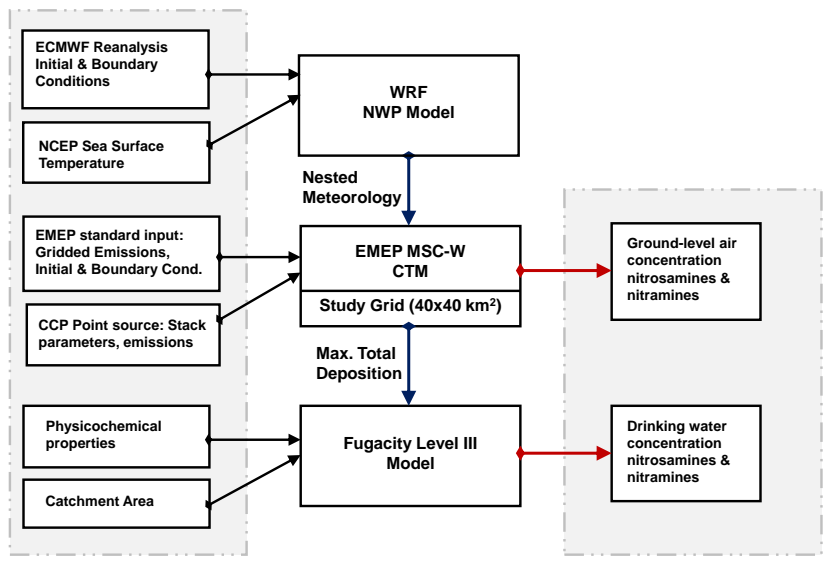

Figure 2. Diagram of the WRF-EMEP model system coupled with a fugacity level III model for application in this study. Left column: standard input data and study-specific input data for the three models; middle column: WRF, EMEP, and fugacity model; right column: model output for comparison to the respective environmental safety limits.

conditions given by the coarse domain ( $50 \mathrm{~km}$ resolution) were therefore not modified.

As part of the WRF-EMEP model system, meteorological input data (pressure, temperature, wind, humidity, etc.) were generated by the Advanced Research WRF (ARW) modelling system Version 3. The ARW dynamics solver integrates the compressible, non-hydrostatic Euler equations. The equations are formulated using a terrain-following hydrostatic-pressure vertical coordinate (Skamarock et al., 2008). The same vertical configuration as in the EMEP model was employed. WRF offers multiple physics options; we selected those that captured best the precipitation pattern in the complex terrain on the west coast of Norway. The Goddard microphysics scheme with ice, snow, and graupel processes was employed for all the domains. The cumulus parameterization was employed only in the 50 and $10 \mathrm{~km}$ domains and the Grell-Devenyi ensemble scheme was selected (for details on the schemes see Skamarock et al., 2008). The Mellor-Yamada-Janjic scheme was employed for the parameterization of the planetary boundary layer and the RRTMG scheme for the long-wave and shortwave radiation. Initial and boundary conditions for WRF were obtained from the European Centre for Medium-Range Weather Forecasts (ECMWF) global atmospheric reanalysis (Dee et al., 2011) at $6 \mathrm{~h}$ intervals with a resolution of $0.75^{\circ}$. Upper-air analysis nudging was employed (four-dimensional data assimilation - FDDA) in the nested domains, and time-varying sea surface temperature (SST) $\left(0.5^{\circ}\right.$ resolution) was employed as input to the model, obtained from the National Centers for Environmental Prediction (NCEP) Real-Time SST archives (ftp://polar.ncep.noaa.gov/pub/history/sst).

WRF was also initialized with the NCEP FNL (Final) Operational Global Analysis data given on $1.0^{\circ} \times 1.0^{\circ}$ grids prepared operationally every 6 hours. Results from the comparison of meteorology from WRF initializations with ECMWF and NCEP FNL data and observations from meteorological stations in the region around Mongstad are presented in Sect. 3.1. In this study we have chosen the meteorological year 2007 for comparability with previous results obtained from the TAPM (The Air Pollution Model) air quality model (Hurley et al., 2005) presented in the "worst case 
scenario" study by Karl et al. (2011) for the same area of Norway. Meteorological input variables computed by the WRF model included surface pressure, sea level pressure, geopotential height, potential temperature, temperature at $2 \mathrm{~m}$, sea surface temperature, soil parameters, ice cover, specific humidity, horizontal winds, friction velocity, and surface fluxes of latent heat and sensible heat. Dispersion parameters (boundary layer height, eddy diffusivity, Obukhov length) are calculated in the EMEP model.

The EMEP model is a CTM developed by EMEP Meteorological Synthesizing Centre - West (EMEP MSC-W) at the Norwegian Meteorological Institute. The model has 20 vertical layers in $\sigma$ coordinates in a terrain-following coordinate system and has generally been used with a $50 \mathrm{~km} \times 50 \mathrm{~km}$ horizontal resolution in the EMEP polar stereographic grid. The model top is defined as $100 \mathrm{hPa}$ and the lowest layer has a depth of about $90 \mathrm{~m}$. The model has been shown to compare very well when evaluated against trace gas measurements of ozone, nitrogen species, and other compounds at rural stations (Jonson et al., 2006; Simpson et al., 2006a, b; Fagerli and Aas, 2008; Aas et al., 2012). We here use open source version rv 4.0 of the EMEP model (released in September 2012), modified for amines and plume rise for this study. The chemical scheme in the EMEP model (here EmChem09 scheme, see Simpson et al., 2012) is flexible in the sense that additional compounds and reactions can be included with the help of a chemical pre-processor. The chemical equations are solved using the TWOSTEP algorithm defined by Verwer et al. (1996) and Verwer and Simpson (1995). Anthropogenic emissions of sulfur oxides $\left(95 \%\right.$ as $\mathrm{SO}_{2}$ and $5 \%$ as particulate $\left.\mathrm{SO}_{4}\right)$, nitrogen oxides $\left(\mathrm{NO}_{\mathrm{x}}=\mathrm{NO}+\mathrm{NO}_{2}\right)$, ammonia $\left(\mathrm{NH}_{3}\right)$, non-methane volatile organic compounds (NMVOC), carbon monoxide (CO), and particulates $\left(\mathrm{PM}_{2.5}\right.$, $\mathrm{PM}_{10}$ ) are interpolated from the TNO-MACC (Monitoring Atmospheric Composition and Climate) (Kuenen et al., 2011 ), approximately $7 \mathrm{~km} \times 7 \mathrm{~km}$, emissions to the required $2 \mathrm{~km} \times 2 \mathrm{~km}$. A more detailed description of the gridded emissions is given in Sect. $\mathrm{S} 1$ in the Supplement. $\mathrm{NO}_{\mathrm{x}}$ emissions from the industrial area at Mongstad are given in Supplement Table S3. Emissions of the power plant (equipped with a CCP) and $\mathrm{NO}_{\mathrm{x}}$ emission from the Mongstad refinery were treated as point sources (Sect. 2.4). Full details of the EMEP MSC-W model are given in Simpson et al. (2012).

By definition, atmospheric transport by diffusion processes are sub-grid mixing processes not resolved by the given resolution of the model. For large grid cells (e.g. $50 \mathrm{~km} \times 50 \mathrm{~km}$ as in the EMEP standard setup), the numerical diffusion will usually be much larger than the physical diffusion in the horizontal direction. Therefore, no additional horizontal diffusion term has been included in the EMEP model when using a $50 \mathrm{~km}$ grid resolution (Simpson et al., 2012). However, at higher resolution scales, the physical diffusion will gradually become more important than numerical diffusion and becomes greater than numerical diffusion for $5 \mathrm{~km} \times 5 \mathrm{~km}$ cell size or below. We estimate that the error re- lated to neglecting horizontal diffusion in the inner domain $(2 \mathrm{~km} \times 2 \mathrm{~km})$ is less than $15 \%$ for the modelled maximum amine ground-level concentrations (details can be found in Sect. S3 of the Supplement).

\subsection{Fugacity level III multimedia model}

Fugacity models are routinely applied to investigate the fate of compounds in a multimedia context (Mackay, 2001). The fugacity level III model was used to simulate concentrations of nitrosamines and nitramines in lake water. The model has four bulk media compartments; air, soil, water, and sediments. The model includes quantitative advective and diffusive transport processes between these compartments parameterized with mass transfer coefficients and transport velocities. Loss processes are by advection (e.g. movement of air and water to outside the model domain in addition to permanent removal of sediment) and degradation of the compound. Deposition is assumed to be constant and the steadystate distribution of the compounds is achieved with equilibrium within the compartments (e.g. between pore water and sediments), but not between bulk media (i.e. sediment and water have different fugacities). Given a parameterization of the evaluative environment, i.e. area and volume of compartments as well as transport coefficients, there is a linear relationship between deposition/emission and concentration in the water phase for a given compound. Fugacity level III models have successfully been applied to a wide range of compounds and environments (Mackay et al., 1996; MacLeod and Mackay, 1999) and are an integrated part of the US EPA software for environmental fate estimation (US EPA, 2012).

Separate fugacity calculations were made for the nitramine of MEA, the nitramine of DEYA, and the nitrosamine of DEYA. The physicochemical parameters for the nitramine of MEA were approximated with data for methylnitramine (MNA). The physicochemical parameters for nitramine and the nitrosamine of DEYA were approximated with data for dimethylnitramine and NDMA, respectively. Degradation rates of nitramines and nitrosamines in the air, soil, water, and sediment were calculated using EPISuite ${ }^{\text {TM }}$ based on standard US EPA methodology (US EPA, 2012). The values for physicochemical parameters of these compounds are summarized in Table S1 in the Supplement. The lake water simulations started with the assumption that the deposition to the lake and its catchment was equivalent to that in the $2 \mathrm{~km} \times 2 \mathrm{~km}$ grid square with the maximum total deposition for each compound determined by the WRF-EMEP model. Parameters for an exemplary lake, typical for small lakes along the west coast of Norway, are summarized in Supplement Table S2. Several of these parameters were varied as part of the sensitivity analyses in this study. 
Table 1. Stack data and emission data of the CCP at Mongstad applied in this study. Data sources: Rao and Rubin (2002), Karl et al. (2011). It is stressed that the stack design and emissions of the $\mathrm{CCP}$ does not represent any existing post-combustion plant.

\begin{tabular}{llr}
\hline Stack parameter & & Value \\
\hline Geographic coordinates (lat|lon) & & $60.809^{\circ} \mathrm{N} \mid 5.036^{\circ} \mathrm{E}$ \\
Stack height $H_{\mathrm{S}}$ & $(\mathrm{m})$ & 60.0 \\
Stack diameter $D$ & $(\mathrm{~m})$ & 7.14 \\
Exhaust gas exit temperature & $\left({ }^{\circ} \mathrm{C}\right)$ & 40.0 \\
Exhaust gas exit velocity $V_{\mathrm{S}}$ & $\left(\mathrm{m} \mathrm{s}^{-1}\right)$ & 10.0 \\
Emission MEA & $\left(\mathrm{g} \mathrm{s}^{-1}\right)$ & 1.2684 \\
Emission DEYA & $\left(\mathrm{g} \mathrm{s}^{-1}\right)$ & 0.1585 \\
Emission NO & $\left(\mathrm{g} \mathrm{s}^{-1}\right)$ & 4.2174 \\
Emission $\mathrm{NO}_{2}$ & $\left(\mathrm{~g} \mathrm{~s}^{-1}\right)$ & 0.2220 \\
\hline
\end{tabular}

\subsection{Point source emissions}

Plume rise determines maximum ground-level concentrations from most point sources, as it typically increases the effective stack height by a factor of 2-10 times the actual release height (Hanna et al., 1982). Since maximum groundlevel concentration is roughly proportional to the inverse square of the effective stack height, it is clear that plume rise can reduce ground-level concentrations by a factor of as much as 100 (Hanna et al., 1982). Plume rise calculations for point sources have been included here in the EMEP model. The so-called "NILU-plume" treatment follows the plume rise equations originally presented by Briggs (1969, 1971, 1975).

Inputs to the NILU-plume rise parameterization are the point source characteristics (stack location, height, diameter, exhaust gas temperature and velocity; see Table 1) and boundary layer meteorology characteristics (air temperature, wind speed, friction velocity, Obukhov length scale, and mixing height). Plume rise for different boundary layer stability conditions (i.e. unstable, neutral, light stable, and stable) is calculated differently where the inverse Obukhov length is used to characterize the boundary layer stability. Point source emissions are injected using a Gaussian distribution centred at the calculated effective emission height to vertically distribute the emissions between the corresponding model layers.

Air temperature and wind speeds from about $45 \mathrm{~m}$ (the WRF-EMEP system's model's lowest layer) are used as approximations for stack-height meteorology. The WRF model also provides friction velocity and Obukhov length data. A fixed surface roughness value of $z_{0}=0.25 \mathrm{~m}$, adequate for rough surfaces of an industrial area (Wieringa, 1992), was applied. Wind speed $u_{z}$ at plume height $z(\mathrm{~m})$ above ground is calculated as:

$u_{z}=u_{z_{\mathrm{ref}}}+\frac{u_{*}}{\kappa} \int_{\nu=z_{\mathrm{ref}}}^{\nu=z} \Phi_{\mathrm{m}}\left(\nu, L^{-1}\right) \frac{1}{v} \mathrm{~d} \nu$,

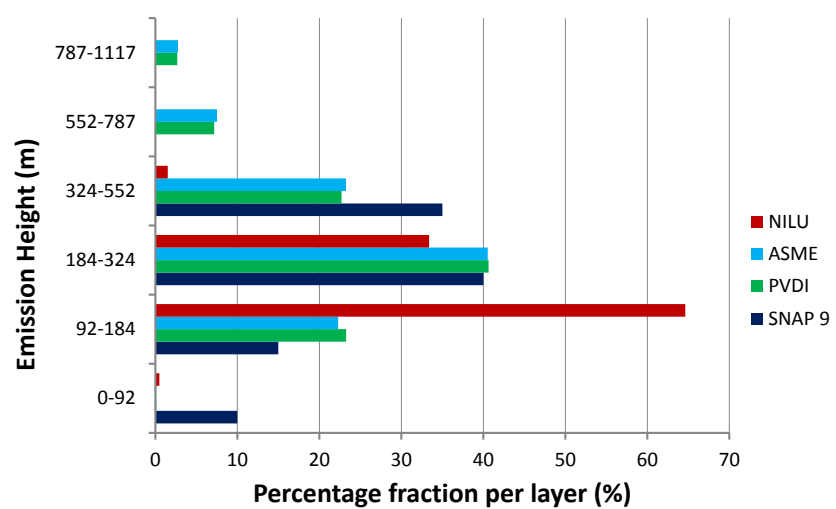

Figure 3. Vertical emission profile of the CCP point source for SNAP category 9 (see text) and for the options NILU Plume, ASME Plume and PVDI Plume in WRF-EMEP calculated for July 2007, using stack parameters of Table 1. Percentage fractions in the six layers for NILU Plume, ASME Plume, and PVDI Plume are based on 8928 online calculated profiles.

where $u_{z_{\text {ref }}}$ is the wind speed at the given reference height $(45 \mathrm{~m}) ; u_{*}$ is the friction velocity; $L^{-1}$ is the inverse of the Obukhov length $L$; and $\kappa$ is the Von Kármán constant (0.41). The Monin-Obukhov similarity function $\Phi_{\mathrm{m}}$ is defined as in Högström (1996). For the stable cases, we use:

$\Phi_{\mathrm{m}}= \begin{cases}1+5.3 \cdot z / L & z / L \leq 1 \\ 5.3+z / L & z / L>1\end{cases}$

For the application of Eqs. (1) and (2), $z / L$ was not restricted to lie in the interval $[-2,0]$ for the unstable cases $(L<0)$, and $[0,1]$ for the stable cases $(L>0)$, as recommended by Högström (1996). The impact of this deviation on the resulting final plume height computed with the WRF-EMEP model based on meteorological data at the Mongstad site in July 2007 was found to be negligible for both unstable and stable conditions. For more details on the above scheme and other recommended schemes, see the final reports from the COST 710 project (Fisher et al., 1998) and Högström (1996). A logic diagram of the NILU Plume algorithm to obtain final plume rise is illustrated in Fig. S1 of the Supplement. Two alternative plume rise options were implemented: "ASME Plume" and "PVDI Plume". A description of these two options and a comparison of the final plume rise calculated by the three different methods are presented in Sect. S2 of the Supplement.

Figure 3 shows the difference between the online calculated vertical emission profiles and the constant profile for Selected Nomenclature for Air Pollution (SNAP) category 9 using the CCP stack characteristics. The NILU Plume option in WRF-EMEP leads to a vertical emission profile with $65 \%$ in the $92-184 \mathrm{~m}$ height layer and $33 \%$ in the 184 $323 \mathrm{~m}$ layer on average for July 2007. In contrast, a (constant) vertical profile of SNAP category 9 ("waste treatment and disposal") apportions ca. $35 \%$ of the CCP emissions in 
the layer $324-552 \mathrm{~m}$. The emission profiles calculated for ASME Plume and PVDI Plume are very similar. These profiles are comparable to SNAP category 9 , but $10 \%$ are predicted to be in layers above $552 \mathrm{~m}$ height. Among the different plume options, NILU Plume has the highest fraction of emissions in the layer $92-184 \mathrm{~m}$ as expected due to its generally low plume rise. The online calculated profiles attribute no emissions to the lowest vertical layer in July 2007. The variability of the online calculated profiles is relatively high; the NILU Plume July average percentage fraction in the layer 92-184 m varies by $\pm 13 \%$. A limitation of the current treatment of plume rise from elevated point sources is the relative coarse vertical resolution of the EMEP model, which may lead to inaccurate attribution of emitted material to vertical model layers, in particular in situations with calculated final plume rise of less than $30 \mathrm{~m}$.

\subsection{Atmospheric chemical data}

The main oxidation pathway in the gas phase is initiated by reaction with the atmospheric hydroxyl $(\mathrm{OH})$ radical (Nielsen et al., 2012b). Among theoretically predicted atmospheric degradation products from the reaction of amines with $\mathrm{OH}$ radicals are aldehydes, amides, imines, nitrosamines, and nitramines (Nielsen et al., 2012b). Amines may react equally fast with atmospheric $\mathrm{NO}_{3}$ radicals during night-time; the possibility of the reaction between MEA and $\mathrm{NO}_{3}$ will be tested in the sensitivity analysis (Sect. 2.7).

Amine chemistry schemes for the $\mathrm{OH}$-initiated oxidation of MEA and DEYA were set based on a simplified photooxidation scheme presented by Nielsen et al. (2012a) (Table 2). The schemes consider $\mathrm{OH}$ reaction, photolysis of nitrosamines, reaction of nitramines with $\mathrm{OH}$, and equilibrium partitioning to the aqueous phase. Rate constants and branching ratios of the MEA and DEYA schemes were adopted from Nielsen et al. (2012b) (Table 2).

In modification to the amine scheme by Nielsen et al. (2012a), the formation of a nitrosamine in the oxidation of MEA was deactivated. Instead, the reaction between NO and the $\mathrm{N}$-alkyl radical (RHN.) leads directly to the imine $(\mathrm{R}=\mathrm{NH})$ with the rate $k_{2} \cdot \mathrm{NO}$. Based on quantum chemical calculations, there is evidence that the nitrosamine from primary amines, despite forming under atmospheric conditions, is in isomerization equilibrium with $\mathrm{RNHNOH}^{+}$which undergoes rapid $\mathrm{H}$ abstraction by $\mathrm{O}_{2}$ to give the corresponding imine (Tang et al., 2012). For the $\mathrm{OH}$-initiated oxidation of MEA, the nitrosamine was not detected in experiments at the outdoor environment chamber facility EUPHORE (European PHOtoREactor) (Nielsen et al., 2011; Karl et al., 2012). The modified scheme allows for reaction between the nitramine and $\mathrm{OH}$ radicals with rate constant $k_{6}$ to form a nitramide $\left(\mathrm{R}(=\mathrm{O}) \mathrm{NR}^{\prime} \mathrm{NO}_{2}\right)$.

\subsection{Deposition and aqueous phase partitioning}

In the atmosphere, amines and their photo-oxidation products are removed by dry and wet deposition processes. Karl et al. (2011) treated dry and wet removal of these compounds in the same way as sulfur dioxide $\left(\mathrm{SO}_{2}\right)$ in dispersion simulations using TAPM v.4 (Hurley et al., 2005). In TAPM calculations using the "tracer mode", $\mathrm{SO}_{2}$ is assumed to be readily dissolved in water and thus totally removed by wet deposition. The efficiency of wet scavenging of amines has been set to $100 \%$ in the TAPM simulations (Karl et al., 2011). In the EMEP model a more realistic approach for the deposition of amines and their products was chosen. Dry deposition and wet deposition characteristics of nitramines and nitrosamines were treated in the same way as for the amines.

Currently, very little is known about the dry deposition behaviour of amines. Since amines are basic substances (MEA: $\mathrm{pKa}=9.5)$, it appears to be more appropriate to treat their dry deposition velocities in the same way as $\mathrm{NH}_{3}$. In the EMEP model, the non-stomatal resistance for $\mathrm{NH}_{3}$ over vegetated surfaces depends upon surface temperature, relative humidity, and the molar acidity ratio, expressed as the concentration ratio of $\mathrm{SO}_{2}$ to $\mathrm{NH}_{3}$ (Simpson et al., 2012). Conversely, the canopy conductance of $\mathrm{SO}_{2}$ is strongly controlled by $\mathrm{NH}_{3}$ levels, and an operational parameterization was included to take into account co-deposition effects for dry deposition of $\mathrm{SO}_{2}$.

Parameterization of the wet deposition processes in the EMEP model includes both in-cloud and below-cloud scavenging of gases and particles (Berge and Jakobsen, 1998; Simpson et al., 2012). By default, the in-cloud scavenging ratio and below-cloud scavenging ratio of nitric acid $\left(\mathrm{HNO}_{3}\right)$ was applied for the wet deposition of amines, nitramines, and nitrosamines. For most ranges of $\mathrm{pH}$ in liquid cloud and rain water, at equilibrium $\mathrm{HNO}_{3}$ is almost entirely in the condensed phase. Calculations by Ge et al. (2011) demonstrated that for the typical atmospheric liquid water content of fogs and clouds at natural acidity of rainwater $(\sim \mathrm{pH} 5.6)$, substantial partitioning of amines to the aqueous phase takes place; thus, $\mathrm{HNO}_{3}$ appears to be a good model for most amines. We further assumed that wet scavenging of amines, nitrosamines, and nitramines occurs through rain and snow. However, many trace gases that are soluble in cloud or rain drops are insoluble in ice because they tend to be expelled as water freezes or to desorb from the ice surface.

The effect of partitioning of amines to the aqueous phase of clouds is that a smaller fraction of the amine is available for gas-phase reaction with $\mathrm{OH}$ and, in turn, less nitrosamines and nitramines are produced in the gas phase. In cloud droplets, nitrosamines are effectively shielded against photolysis due to the screening effect of dissolved organic compounds (Hutchings et al., 2010). This implies a longer lifetime of nitrosamines in clouds than in dry air. In the parameterization of the aqueous phase chemistry of amines, we assumed that the Henry's law is fulfilled 
Table 2. Atmospheric photo-oxidation scheme for MEA (primary amine $\mathrm{RNH}_{2}$ ) and DEYA (secondary amine, $\mathrm{RR}{ }^{\prime} \mathrm{NH}$ ) implemented in the EMEP model. Branching of the amine chemistry scheme, rate constants $(k)$, and photolysis frequency $(j)$ for nitrosamine photolysis were adopted with modifications from Nielsen et al. (2012a). The branch leading to nitrosamines was deactivated for MEA; instead the imine of MEA is formed directly in reaction with NO.

\begin{tabular}{|c|c|c|c|c|c|c|c|c|c|}
\hline No. & & Reaction educts & & & \multicolumn{4}{|c|}{ Reaction products } & \multirow{2}{*}{$\begin{array}{r}\text { Rate constant } \\
k_{1 \mathrm{a}}(\mathrm{MEA})\end{array}$} \\
\hline 1 & & $\mathrm{RNH}_{2}+\mathrm{OH}$ & $\rightarrow$ & & & & RNH. & & \\
\hline 2 & & $\mathrm{RNH} \cdot+\mathrm{NO}$ & $\rightarrow$ & & & $\mathrm{R}=\mathrm{N}$ & $\mathrm{H}+\mathrm{HONO}$ & & $k_{2}$ (MEA) \\
\hline 3 & & $\mathrm{RNH} \cdot+\mathrm{NO}_{2}$ & $\rightarrow$ & & & & $\mathrm{RNHNO}_{2}$ & & $k_{3}$ (MEA) \\
\hline 4 & & $\mathrm{RNH} \cdot+\mathrm{NO}_{2}$ & $\rightarrow$ & & & $\mathrm{R}=\mathrm{N}$ & $\mathrm{H}+\mathrm{HONO}$ & & $k_{4}(\mathrm{MEA})$ \\
\hline 5 & & $\mathrm{RNH} \cdot+\mathrm{O}_{2}$ & $\rightarrow$ & & & & $\mathrm{NH}+\mathrm{HO}_{2}$ & & $k_{5}(\mathrm{MEA})$ \\
\hline 6 & & $\mathrm{RNHNO}_{2}+\mathrm{OH}$ & $\rightarrow$ & & & $\mathrm{R}(=\mathrm{O}) \mathrm{NHI}$ & $\mathrm{O}_{2}+\mathrm{HO}_{2}$ & & $k_{6}(\mathrm{MEA})$ \\
\hline 7 & & $\mathrm{RNH}_{2}+\mathrm{NO}_{3}$ & $\rightarrow$ & & & & $\mathrm{RNH}$ & & $k_{7}(\mathrm{MEA})^{\mathrm{g}}$ \\
\hline 8 & & $\mathrm{RR}^{\prime} \mathrm{NH}+\mathrm{OH}$ & $\rightarrow$ & & & & $\mathrm{RR}^{\prime} \mathrm{N}$ & & $k_{1 \mathrm{a}}(\mathrm{DEYA})$ \\
\hline 9 & & $\mathrm{RR}^{\prime} \mathrm{N} \cdot+\mathrm{NO}$ & $\rightarrow$ & & & & $\mathrm{RNR}^{\prime} \mathrm{NO}$ & & $k_{2}$ (DEYA) \\
\hline 10 & & $\mathrm{RR}^{\prime} \mathrm{N} \cdot+\mathrm{NO}_{2}$ & $\rightarrow$ & $0.5 \mathrm{RI}$ & $\mathrm{NR}^{\prime} \mathrm{NO}_{2}+0$ & $.5 \mathrm{R}=\mathrm{NR}^{\prime}+$ & $0.5 \mathrm{HONO}$ & & $k_{3}$ (DEYA) \\
\hline 11 & & $\mathrm{RR}^{\prime} \mathrm{N} \cdot+\mathrm{O}_{2}$ & $\rightarrow$ & & & & $\mathrm{NH}+\mathrm{HO}_{2}$ & & $k_{5}$ (DEYA) \\
\hline 12 & & $\mathrm{RNR}^{\prime} \mathrm{NO}_{2}+\mathrm{OH}$ & $\rightarrow$ & & & $\mathrm{R}(=\mathrm{O}) \mathrm{NR}^{\prime} \mathrm{I}$ & $\mathrm{O}_{2}+\mathrm{HO}_{2}$ & & $k_{6}$ (DEYA) \\
\hline 13 & & $\mathrm{RNR}^{\prime} \mathrm{NO}+\mathrm{h} v$ & $\rightarrow$ & & & & $\mathrm{R}^{\prime} \mathrm{N} \cdot+\mathrm{NO}$ & & $j_{1}$ (DEYA) \\
\hline Comp. & $k_{1}^{\mathrm{a}, \mathrm{b}}$ & $k_{2}{ }^{\mathrm{a}, \mathrm{d}}$ & $k_{6}{ }^{\mathrm{a}, \mathrm{d}}$ & $k_{4}{ }^{\mathrm{a}}$ & $k_{1 \mathrm{a}} / k_{1} \mathrm{~d}$ & $k_{2} / k_{3} \mathrm{~d}, \mathrm{f}$ & $k_{4} / k_{3} \mathrm{d,f}$ & $k_{5} / k_{3} \mathrm{~d}, \mathrm{f}$ & $j_{1} / j_{\left(\mathrm{NO}_{2}\right)}{ }^{\mathrm{d}}$ \\
\hline MEA & $7.61 \times 10^{-11 \mathrm{c}}$ & $8.32 \times 10^{-14 \mathrm{e}}$ & $3.5 \times 10^{-12}$ & $7.0 \times 10^{-14}$ & 0.08 & 0.26 & 0.22 & $3.9 \times 10^{-7}$ & - \\
\hline DEYA & $7.40 \times 10^{-11 \mathrm{c}}$ & $2.24 \times 10^{-13}$ & $4.6 \times 10^{-12}$ & 0.0 & 0.60 & 0.70 & 0.0 & $1.1 \times 10^{-6}$ & 0.3 \\
\hline
\end{tabular}

${ }^{\mathrm{a}}$ Unit: $\mathrm{cm}^{3}$ molecule ${ }^{-1} \mathrm{~s}^{-1}$, photolysis rates in units $\mathrm{s}^{-1}$.

${ }^{\mathrm{b}}$ Rate constant $k_{1}$ is the overall rate constant of the $\mathrm{OH}+$ amine reaction.

${ }^{\mathrm{c}}$ Reference: Onel et al. (2012).

${ }^{\mathrm{d}}$ Reference: Nielsen et al. (2012a).

${ }^{\mathrm{e}}$ Reaction forms imine instead of nitrosamine.

${ }^{f}$ Rate constant $k_{3}=3.20 \times 10^{-13} \mathrm{~cm}^{3}$ molecule $\mathrm{s}^{-1} \mathrm{~s}^{-1}$. Reference: Lazarou et al. (1994).

g Rate constant $k_{7}=1.5 \times 10^{-13} \mathrm{~cm}^{3}$ molecule ${ }^{-1} \mathrm{~s}^{-1}$. Reference: Karl et al. (2012). Reaction MEA $+\mathrm{NO}_{3}$ was only taken into account in the sensitivity test case KNO3M (Sect. 2.7).

(Hutchings et al., 2010). Phase partitioning equilibrium between gas phase and aqueous phase for amines, nitramines, and nitrosamines according to Henry's law as listed in Supplement Table S5 was implemented in the model. These equilibrium coefficients for the given compounds were consistent with the values used in the fugacity model (Sect. 2.3). In the EMEP model, local cloud fraction, defined in the meteorological input fields, is used as an approximate value for the fractional cloud volume. The fraction of the total (gas + aqueous) mass remaining in the interstitial cloud air $\left(f_{\mathrm{g}}\right)$ and the fraction absorbed by cloud droplets $\left(f_{\mathrm{aq}}\right)$ is calculated as (Simpson et al., 2012):

$f_{\mathrm{aq}}=1-f_{\mathrm{g}}=\frac{\left[C_{\mathrm{aq}}\right]}{\left[C_{T}\right]}=\frac{1}{1+(H R T \alpha)^{-1}}$,

where $R$ is the universal gas constant, $T$ is air temperature, $H$ is the Henry's law coefficient, and $\alpha$ is the volume fraction of liquid cloud water.

\subsection{Sensitivity analysis}

Karl et al. (2011) identified major uncertainties in the description of processes in the atmosphere and in the environmental fate due to uncertain atmospheric chemical data, physicochemical properties, and biodegradability. The sensitivity of model results to several of these was explored here. Sensitivity was tested either by variation of a specific param- eter, by increasing or decreasing its value by a certain amount compared to the reference value, or by switching off a specific process. The latter was done when the process was considered to be highly uncertain, in particular when the process has not been evaluated by experimental data. In the last 3 years more studies on the chemical kinetic data of MEA have become available. Hence, published chemical data that were associated with the smallest uncertainties was used as a reference value. For test cases with chemical parameters, the actual uncertainty could be larger than the uncertainty based on available literature values, but for practical reasons it was assumed that the uncertainty range of the chemical parameter was covered by the currently published data.

Atmospheric test cases were developed to assess uncertainties in dispersion characteristics, atmospheric chemistry, phase partitioning, and deposition. A summary of the atmospheric cases and the parameter settings of the baseline simulation (case BASE) and of the cases with parameter variation are given in Table 3. For each sensitivity test, the EMEP model was rerun on 10 and $2 \mathrm{~km}$ domains. Four cases were made to study uncertainties of the MEA chemistry mechanism, including tests on (1) the rate coefficient of the reaction between MEA and $\mathrm{OH}, k(\mathrm{MEA}+\mathrm{OH})$, (case $\mathrm{KOHM})$; (2) the rate coefficient of the reaction between MEA and $\mathrm{NO}_{3}, k\left(\mathrm{MEA}+\mathrm{NO}_{3}\right.$ ), (case $\left.\mathrm{KNO} 3 \mathrm{M}\right)$; (3) the branching ratio for $\mathrm{H}$ abstraction at the $\mathrm{NH}_{2}$ group in the reaction between 
MEA and OH (case YIELD); and (4) the rate coefficient between MEA-nitramine and $\mathrm{OH}, k(\mathrm{MEA}-$ nitramine $+\mathrm{OH})$, (case KNIM). It was assumed that the same products form with the same yield through the $\mathrm{NO}_{3}$ reaction as through the $\mathrm{OH}$ reaction of MEA. There is experimental and theoretical evidence that $\mathrm{NO}_{3}$ reaction with primary and secondary amines occurs via $\mathrm{H}$ abstraction (Nielsen et al., 2012b; T. Kurtén, personal communication, 2011). Therefore, the assumption on the product spectrum of the MEA $+\mathrm{NO}_{3}$ reaction appears to be reasonable.

Additional test cases addressed the vertical emission profile and plume dispersion (case PLUME) and the wet removal of MEA and MEA-nitramine (case WDEP). Partitioning to the aqueous phase of clouds was tested in one sensitivity test (case AQP), while it was deactivated in the reference simulation and all other simulations. Uncertainties of the processes related to the secondary amine (i.e. DEYA) were not studied.

In order to test how different choices for parameters of the fugacity model affect drinking water concentration, seven cases were set up. Tested model aspects include lake residence time, soil depth, fraction of carbon in soil and suspended sediment, and degradation rates for nitrosamines and nitramines (Table 4). We used two sets of degradation rates for nitrosamines and nitramines in all compartments as detailed in Table 4, model aspects "degradation rates nitramines" and "degradation rates nitrosamines". Our baseline parameter values were chosen to reflect ultimate degradation (i.e. full degradation of the compound), while the shorter half-lives were thought of as degradation rates for the compound to transform into a metabolite.

\section{Results}

\subsection{Evaluation of WRF meteorology}

The WRF-EMEP model used ECMWF meteorological data for the baseline simulation and for the other case simulations. In this work, data from five monitoring stations (Bergen, Fedje, Flesland, Takle, and Kvamskogen) with temperature, relative humidity and wind speed on an hourly basis have been analysed. Supplement Table S6 provides an overview of the meteorological stations located in the wider region around Bergen. The performance of the WRF model was evaluated by comparison of yearly wind roses, daily averages of wind direction, wind speed, and temperature. Two different meteorological data sources - NCEP FNL and ECMWF - were included in the comparison to station monitoring data. Section S4 in the Supplement documents the results of this comparison. Wind roses for 2007 predicted by WRF using ECMWF meteorological data compared well with observation-based wind roses (Supplement Fig. S4).

Precipitation data for 2007 has been analysed at 14 stations in the region of Mongstad. Precipitation reached high values in the area of Mongstad, with accumulated monthly values up to $500 \mathrm{~mm}$ at the stations of Takle and Mongstad, and $300 \mathrm{~mm}$ at Bergen and Flesland. High amounts of precipitation were present during the whole year, June being the only month with a precipitation amount lower than $50 \mathrm{~mm}$. Analysis of the precipitation data on a weekly basis for 2007 showed that the WRF model underestimated the observed precipitation amount at most stations in the study area (Fig. 4). In particular, the precipitation peaks in early spring and in autumn were not captured by the model. However, the weekly pattern of observed precipitation is well reproduced. Given the general uncertainty associated with modelling precipitation amounts (factor of $2-3$ or higher) with current state-of-the-art models, the agreement is satisfactory. Some of the stations are extremely difficult to be represented by the model. For instance, Frøyset, the station closest to Mongstad, is situated in the Fensfjorden, which has its own fjord wind system. The agreement between model-predicted and observed precipitation was slightly better with ECMWF data than with NCEP FNL data.

The total amount of precipitation for 2007 was above $2000 \mathrm{~mm}$ in the coastal parts, and between 3000 and $4000 \mathrm{~mm}$ in the mountain parts of the Mongstad region (Fig. S7 in the Supplement). Precipitation amount is related to the orography of the landscape, indicating that orographic rainfall is of great importance in the wider region of Bergen. During 2007, the precipitation was between 10-30\% higher than in a normal year, considering a normal year as the average from 1971 to 2000 . Inside the study area, extending $20 \mathrm{~km}$ to the east of Mongstad, the WRF model predicts a maximum precipitation amount of $\sim 3000 \mathrm{~mm}$ (Supplement Fig. S7b and c). In the coastal part, precipitation is predicted to be below $1500 \mathrm{~mm}$, lower than the observationbased estimate. Based on comparison of monthly averages it is concluded that the modelled annual precipitation amount in the coastal part is up to a factor of 2 lower than observed.

\subsection{Evaluation of EMEP model air concentrations}

Modelled time series of ground air concentrations of $\mathrm{O}_{3}$, $\mathrm{O}_{\mathrm{x}}\left(\mathrm{O}_{\mathrm{x}}=\mathrm{O}_{3}+\mathrm{NO}_{2}\right)$, $\mathrm{NO}$, and $\mathrm{NO}_{2}$ were compared to observed data at two air quality monitoring sites Hamna and Leirvåg located in proximity (within a radius of $3 \mathrm{~km}$ ) of the Mongstad refinery. Figure 5 shows a comparison of $\mathrm{O}_{3}$, $\mathrm{NO}$, and $\mathrm{NO}_{2}$ air concentrations (as mixing ratios in ppbv) for the time period of 1 January to 30 September 2007 at Hamna station between WRF-EMEP model data and observed data. For ozone concentrations, WRF-EMEP reached good agreement with observed data at Hamna. The modelled $\mathrm{O}_{3}$ follows both monthly trends and variations of the monitored time series. Yearly average (2007) modelled $\mathrm{NO}_{2}$ concentrations at Hamna and Leirvåg were 4.9 and $6.5 \mu \mathrm{g} \mathrm{m}^{-3}$, respectively, in reasonable agreement with the monitored average concentrations of 7.4 and $4.6 \mu \mathrm{g} \mathrm{m}^{-3}$, respectively. The modelled peak $\mathrm{NO}_{2}$ concentrations agree with the monitored peaks although the timing of the peaks is not exactly reproduced. 
Table 3. Summary of model aspects included in the sensitivity analysis of the EMEP model. Changes of chemical/physiochemical properties were only done for MEA and MEA-nitramine. Rate constants given in unit $\mathrm{cm}^{3}$ molecule ${ }^{-1} \mathrm{~s}^{-1}$.

\begin{tabular}{llrr}
\hline Model aspect & Case name & Baseline & Alternate \\
\hline Vertical emission profile & PLUME & NILU plume & PVDI plume \\
Rate constant $k$ (MEA $+\mathrm{OH})$ & KOHM & $7.6 \times 10^{-11}$ & $9.2 \times 10^{-11}$ \\
Rate constant $k\left(\mathrm{MEA}+\mathrm{NO}_{3}\right)$ & KNO3M & 0.0 & $1.5 \times 10^{-13}$ \\
Branching ratio $\mathrm{H}$ abstr. at $\mathrm{NH}_{2}$ group & YIELD & 0.08 & 0.16 \\
Rate constant $k$ (MEA-nitramine $+\mathrm{OH})$ & KNIM & $1.48 \times 10^{-11}$ & $3.5 \times 10^{-12}$ \\
Aqueous phase partitioning & $\mathrm{AQP}$ & no & yes \\
Wet deposition & WDEP & as $\mathrm{HNO}_{3}$ & as $\mathrm{SO}_{2}$ \\
\hline
\end{tabular}
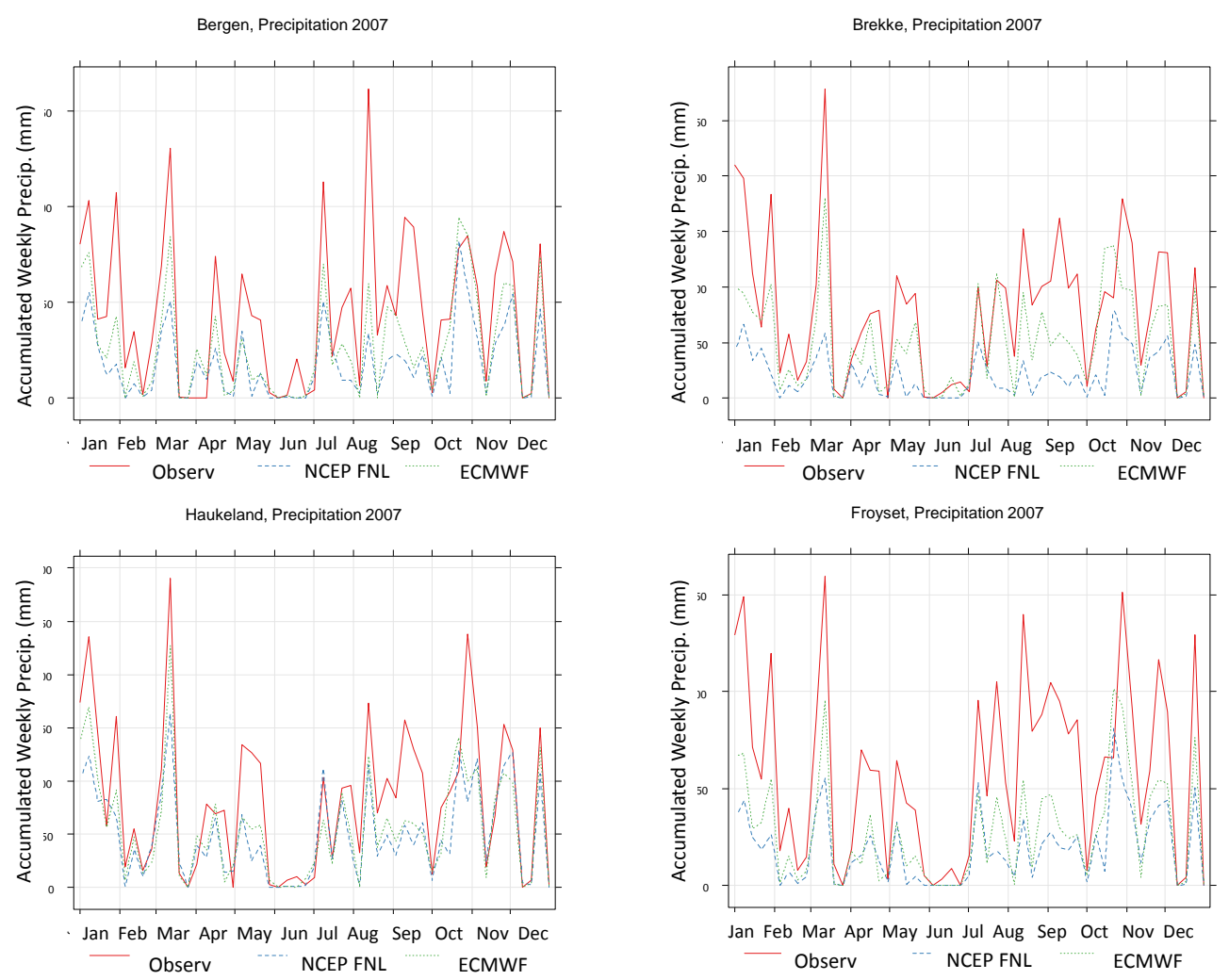

Figure 4. Comparison of precipitation amount (mm) time series for 2007 at Bergen, Brekke, Haukeland, and Frøyset based on weekly intervals from observation (red line), WRF model with ECMWF data (green dashed line) and WRF model with NCEP FNL data (blue dashed line).

In the spring months (March-April), modelled $\mathrm{NO}_{2}$ was lower than the observed data. In the summer months (JuneAugust) the agreement between modelled and observed $\mathrm{NO}_{2}$ was better, showing that WRF-EMEP is capable of reproducing the photochemical reactivity at Mongstad. The yearly average (2007) modelled NO concentration at Hamna was $0.65 \mu \mathrm{g} \mathrm{m}^{-3}(\sim 0.5 \mathrm{ppbv})$. The modelled NO concentrations were in general lower than monitored data. Due to the titration effect, it is extremely difficult to simulate $\mathrm{NO}$ and $\mathrm{NO}_{2}$ concentrations close to the emission source (Mongstad refinery). It is therefore preferable to compare the sum of $\mathrm{O}_{3}$ and $\mathrm{NO}_{2}$ concentrations. Observed concentration of $\mathrm{O}_{\mathrm{x}}$ is reproduced quite well by the WRF-EMEP model, both in terms of absolute values and in terms of variability. Also, the monthly trends matches.

The good match with ozone observations is important for the simulation of amine degradation, since ozone is the main photochemical precursor of $\mathrm{OH}$ radicals. The modelled $\mathrm{OH}$ concentrations at Hamna station in July reached a midday maximum of $\sim 1.2 \times 10^{7}$ molecules $\mathrm{cm}^{-3}$ (Fig. 6a). The $24 \mathrm{~h}$ averaged $\mathrm{OH}$ concentration was $2.6 \times$ $10^{6}$ molecules $\mathrm{cm}^{-3}$, in good agreement with previous model simulations for the Mongstad region employing the model COSMO/MUSCAT (Wolke et al., 2004) presented in the 
Table 4. Summary of model aspects included in the sensitivity analysis of the fugacity model. Each parameter was changed independently. The degradation rates (expressed as degradation half-life in days) refer to the values for the compartments air/soil/water/sediment. Baseline degradation rates refer to ultimate degradation of the compound. For the alternate of the model aspect "degradation rates nitramines", the degradation rate of nitramines (MEA-nitramine and DEYA-nitramine) is based on the calculated primary degradation half-lives of methylnitramine (MNA). For the alternate of the model aspect "degradation rates nitrosamines", the degradation rate of DEYA-nitrosamine is based on the calculated primary degradation half-lives of N-nitrosodimethylamine (NDMA).

\begin{tabular}{|c|c|c|c|}
\hline Model aspect & Case name & Baseline & Alternate \\
\hline $\begin{array}{l}\text { Hydrology - residence time } \\
\text { through lake depth }\end{array}$ & HydDep & $10 \mathrm{~m}$ & $\begin{array}{r}5 \mathrm{~m} \\
20 \mathrm{~m}\end{array}$ \\
\hline $\begin{array}{l}\text { Hydrology - residence time } \\
\text { through lake area }\end{array}$ & HydArea & $0.16 \mathrm{~km}^{2}$ & $\begin{array}{l}0.08 \mathrm{~km}^{2} \\
0.32 \mathrm{~km}^{2}\end{array}$ \\
\hline Soil depth & SoilDep & $0.1 \mathrm{~m}$ & $\begin{array}{r}0.05 \mathrm{~m} \\
0.2 \mathrm{~m}\end{array}$ \\
\hline $\begin{array}{l}\text { Chemistry - fraction } \\
\text { organic carbon in soil }\end{array}$ & ChemSoil & 0.014 & $\begin{array}{l}0.007 \\
0.028\end{array}$ \\
\hline $\begin{array}{l}\text { Chemistry - fraction org. } \\
\text { carbon in susp. sediments }\end{array}$ & ChemSed & 0.14 & $\begin{array}{l}0.07 \\
0.28\end{array}$ \\
\hline Degradation rates nitramines & DegRateMNA & $8.5 / 30 / 15 / 135$ days & 8.5/4.6/2.3/21 days \\
\hline Degradation rates nitrosamines & DegRateNDMA & 4.2/38/23/207 days & $4.2 / 5 / 0.7 / 2.7$ days \\
\hline
\end{tabular}
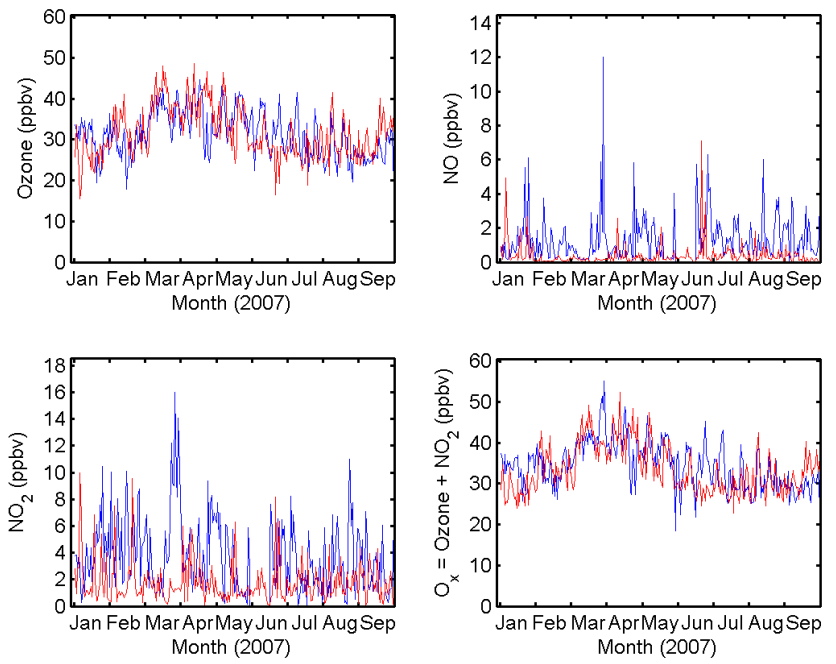

Figure 5. Comparison of air quality data (daily averages of $\mathrm{O}_{3}$, $\mathrm{NO}, \mathrm{NO}_{2}, \mathrm{O}_{\mathrm{x}}$ ) at Hamna, January-September 2007. The modelled ground air mixing ratios (ppbv) with WRF-EMEP (red lines) and monitored mixing ratios (ppbv; blue lines). Data gap in observed $\mathrm{NO}$ and $\mathrm{NO}_{2}$ data from 28 May to 14 June.

report by Nielsen et al. (2012a). The modelled MEA concentrations at Hamna station revealed peak concentrations of $>100 \mathrm{ng} \mathrm{m}^{-3}$ on several days in July (Fig. 6a), when Hamna station was downwind the CCP at Mongstad receiving the plume containing high amine and $\mathrm{NO}_{\mathrm{x}}$ concentrations. The peaks were associated with low plume rise and injection of $>90 \%$ of the amine emissions into the second model layer (92-184 m). Enhanced MEA concentrations were frequently concurrent with suppressed $\mathrm{OH}$ concentrations, probably due to high $\mathrm{NO}_{2}$ in the plume. The vertical resolution of the model with the lowest level of ca. $90 \mathrm{~m}$ height has strong implications for the modelled MEA ground-level concentrations. However, the timescale for vertical mixing in the unstable boundary layer is typically much less than the chemical lifetime of MEA in the reaction with $\mathrm{OH}$ radicals (ca. 1-2 $\mathrm{h}$ during daytime at Mongstad). We therefore expect that the relatively coarse vertical resolution of the EMEP model is adequate for the simulation of amines, especially since we are mainly interested in yearly average concentrations.

\subsection{Evaluation of atmospheric production yields}

In order to evaluate the modelled atmospheric production yield of nitramines in WRF-EMEP, the reference simulation included emissions of a chemically inert compound (passive tracer) with the same emission rate as MEA. Deposition and chemical reaction of nitramines was deactivated in this test run. The difference between the air concentration surface fields of the reactive amine and the inert tracer provides an estimate of the amine amount that reacted with $\mathrm{OH}$. The maximum of the reacted amine was at a distance of about 5-6 km to the west of the CCP Mongstad, computed as a 
a)

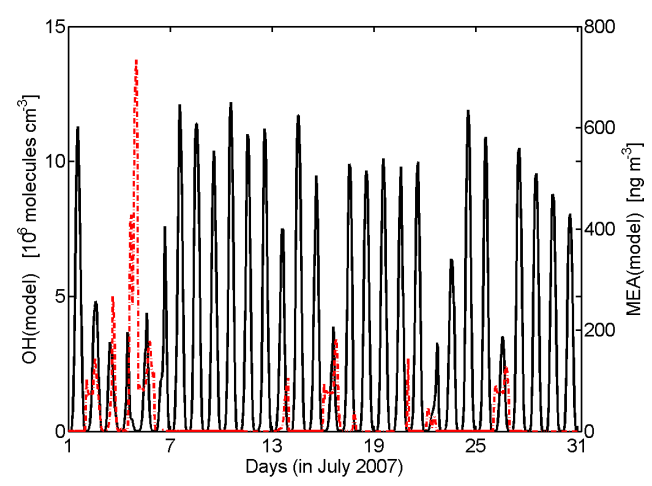

b)

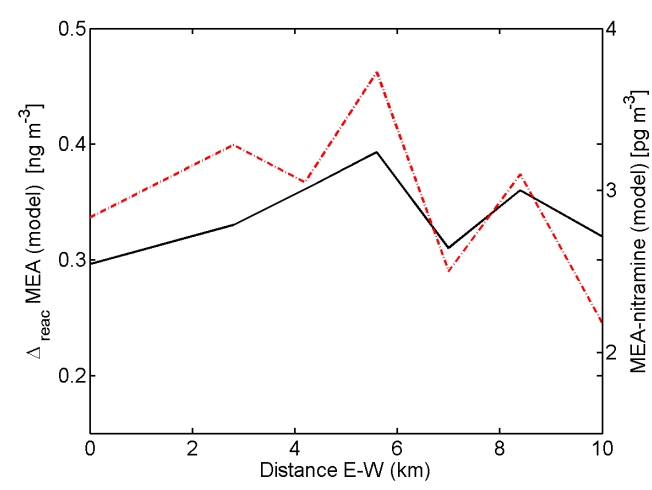

Figure 6. Photochemical production of MEA-nitramine in WRF-EMEP: (a) modelled gas-phase concentration of OH (black line) and MEA (red dash-dotted line) at Mongstad in July 2007 and (b) modelled yearly averaged reacted amount (black line) of the primary amine MEA $\left(\Delta_{\text {reac }}\right.$; calculated as the concentration difference between MEA and an inert tracer emitted with the same amount of $1.27 \mathrm{~g} \mathrm{~s}^{-1}$ ) and air concentration of MEA-nitramine (red dash-dotted line) as function of distance from the CCP Mongstad in E-W direction.

concentration difference of $0.39 \mathrm{ng} \mathrm{m}^{-3}$. The corresponding air concentration of MEA at the location of the maximum reactivity was $24.8 \mathrm{ng} \mathrm{m}^{-3}$. Thus only $1.6 \%$ of MEA was degraded by $\mathrm{OH}$ reaction at the location. The corresponding modelled air concentration of the MEA-nitramine - produced in the $\mathrm{OH}$ reaction of MEA - was $4 \times 10^{-3} \mathrm{ng} \mathrm{m}^{-3}$. Due to the instantaneous volume mixing of the emissions from Mongstad (from the power plant equipped with $\mathrm{CCP}$ and the refinery) in the EMEP model, emitted NO immediately reacts with $\mathrm{O}_{3}$ to form $\mathrm{NO}_{2}$ and $\mathrm{O}_{2}$, thereby lowering ozone concentrations at Mongstad. In addition, the reaction of $\mathrm{OH}$ with $\mathrm{NO}_{2}$ will be a relevant sink for $\mathrm{OH}$ radicals directly at the industrial source. Therefore, close to Mongstad, elevated $\mathrm{NO}_{2}$ concentrations led to a reduced net production of $\mathrm{OH}$ radicals and hence less photochemical reactivity of the amine. The spatial correlation between the reactivity of MEA and the MEA-nitramine concentration (Fig. 6b), confirms the capability of the model to reliably predict the photochemical production of the nitramine.

The apparent percentage yield of nitramine was calculated from the ratio of nitramine produced to MEA reacted and was found to be $0.87 \%$. This is within the range of estimated nitramine yields for the $\mathrm{OH}$ reaction of MEA reported by Nielsen et al. (2011). Apparent product yields of MEAnitramine in photo-oxidation experiments in the large photo reactor facility EUPHORE were 0.3 to $1.5 \%$ depending on the $\mathrm{NO}_{\mathrm{x}}$-level in the experiment. For urban regions predicted MEA-nitramine yields ranged between 0.3 to $1.0 \%$ and for rural regions ranged between 0.005 and $0.3 \%$ (Nielsen et al., 2011). A reason for the higher nitramine yield calculated from WRF-EMEP might be that the reaction between MEAnitramine and $\mathrm{OH}$ radicals was not considered in the test, while it constitutes a relevant loss path of the nitramine in chamber experiments. The modelled $\mathrm{NO}_{2}$ yearly average air concentrations in the area around the maximum photochemi- cal production were $4-5 \mu \mathrm{g} \mathrm{m}^{-3}$ (2.5-3.5 ppbv). The area can be described as moderately polluted.

\subsection{Results of the simulations}

Yearly average surface air concentrations and accumulated total deposition of the sum of nitrosamines and nitramines calculated for the different parameter variation cases were compared for the study grid of $40 \mathrm{~km} \times 40 \mathrm{~km}$ with the CCP in the centre. Wet and dry deposition of nitrosamines and nitramines was used to drive the fugacity model to compute average concentrations of nitrosamines and nitramines in the water compartment. Based on the maximum total deposition fluxes of the sum of nitrosamine and nitramines inside the study area, a worst case for the atmospheric fate of MEA and DEYA was set up by using the parameter choice which resulted in the higher deposition flux when comparing the respective simulation case to the baseline case. Correspondingly, a second worst case was set up for the soil/water/sediment fate, based on the respective parameter value choices that gave the higher drinking water concentration in the standard lake. Table 5 summarizes the parameter value choices for the worst cases addressing atmospheric fate and soil/water/sediment fate, together with the respective baseline cases.

While the response to a change of chemical parameters results in a clear response of the resulting air concentration, a change of the plume rise parameterization also causes a change in the spatial pattern. To test if the selected parameter choice for the worst case (Table 5) gives the highest concentration, the worst case was also run with PVDI Plume (replacing NILU Plume).

The spatial distribution of annual average air concentration of amines (MEA + DEYA) at ground level was similar for all simulations that used the plume rise parameterization NILU Plume, with a first maximum in the grid cell of the CCP plant, and a second somewhat lower maximum 
a)

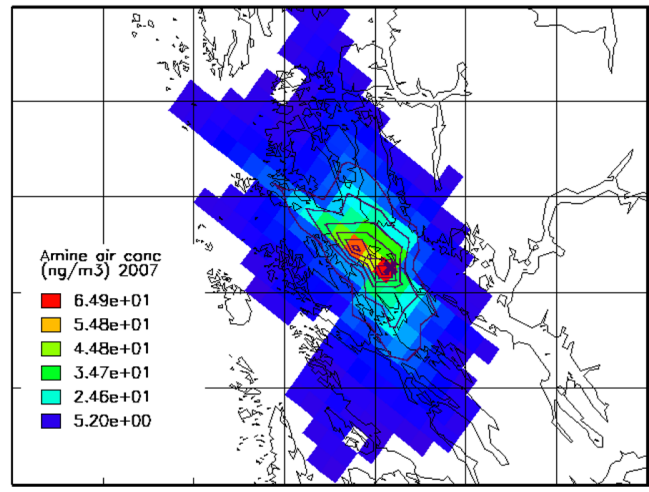

b)

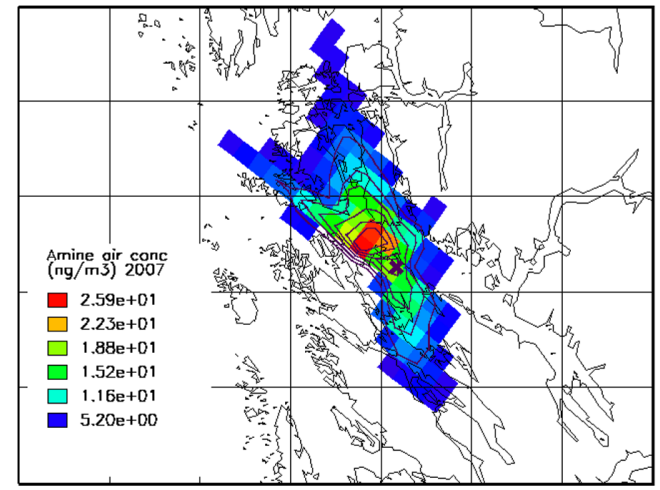

Figure 7. Spatial distribution of the annual average (year 2007) ground-level air concentration of amines (sum of MEA and DEYA, in ng $\mathrm{m}^{-3}$ ) computed by WRF-EMEP in the (a) baseline case (BASE) and in (b) case PLUME which uses the PVDI Plume parameterization. Different concentration scales are used for better clarity of the dispersion patterns. Values below the smallest legend entry (here $5.2 \mathrm{ng} \mathrm{m}^{-3}$ ) are not shown. The location of CCP Mongstad is marked by a purple X. The grid cells divided by black lines illustrate an extent of $10 \mathrm{~km} \times 10 \mathrm{~km}$.

Table 5. Worst case for the atmospheric fate and worst case for the soil/water/sediment fate and the respective baseline cases. Worst cases were designed based on results from the parameter variation cases. For explanations and units on the model aspects see Tables 3 and 4.

\begin{tabular}{|c|c|c|c|c|c|}
\hline \multicolumn{3}{|c|}{ Atmospheric fate } & \multicolumn{3}{|c|}{ Soil/water/sediment fate } \\
\hline Model aspect & Baseline & Worst case & Model aspect & Baseline & Worst case \\
\hline $\begin{array}{l}\text { Vertical emission } \\
\text { profile }\end{array}$ & NILU Plume & NILU Plume & $\begin{array}{l}\text { Residence time, } \\
\text { lake depth }\end{array}$ & $10 \mathrm{~m}$ & $5 \mathrm{~m}$ \\
\hline$k(\mathrm{MEA}+\mathrm{OH})$ & $7.6 \times 10^{-11}$ & $9.2 \times 10^{-11}$ & $\begin{array}{l}\text { Residence time, } \\
\text { lake area }\end{array}$ & $0.16 \mathrm{~km}^{2}$ & $0.08 \mathrm{~km}^{2}$ \\
\hline$k\left(\mathrm{MEA}+\mathrm{NO}_{3}\right)$ & 0.0 & $1.5 \times 10^{-13}$ & Soil depth & $0.1 \mathrm{~m}$ & $0.05 \mathrm{~m}$ \\
\hline $\begin{array}{l}\text { Branching ratio } \\
\text { at } \mathrm{NH}_{2} \text { group }\end{array}$ & 0.08 & 0.16 & $\begin{array}{l}\text { Chemistry, fraction } \\
\text { OC soil }\end{array}$ & 0.014 & 0.007 \\
\hline $\begin{array}{l}k \text { (MEA-nitramine } \\
+\mathrm{OH})\end{array}$ & $1.48 \times 10^{-11}$ & $3.5 \times 10^{-12}$ & $\begin{array}{l}\text { Chemistry, fraction } \\
\text { OC susp. sediment }\end{array}$ & 0.14 & 0.14 \\
\hline $\begin{array}{l}\text { Aqueous phase } \\
\text { partitioning }\end{array}$ & no & no & $\begin{array}{l}\text { Degradation rate, } \\
\text { nitramines }\end{array}$ & $\begin{array}{r}8.5 / 30 / 15 / \\
135 \text { days }\end{array}$ & $\begin{array}{r}8.5 / 30 / 15 / \\
135 \text { days }\end{array}$ \\
\hline Wet deposition & $\mathrm{HNO}_{3}$ & $\mathrm{HNO}_{3}$ & $\begin{array}{l}\text { Degradation rate, } \\
\text { nitrosamines }\end{array}$ & $\begin{array}{r}4.2 / 38 / 23 / \\
207 \text { days }\end{array}$ & $\begin{array}{r}4.2 / 38 / 23 / \\
207 \text { days }\end{array}$ \\
\hline
\end{tabular}

about $4 \mathrm{~km}$ north-west of Mongstad (Fig. 7a). The maximum surface concentration of amines was $65 \mathrm{ng} \mathrm{m}^{-3}$ in the baseline run. Increasing the rate constant of the $\mathrm{MEA}+\mathrm{OH}$ reaction (case KOHM) by $21 \%$ had a negligible effect $(<0.2 \%)$ on the maximum surface concentration. Similarly, the additional reaction of $\mathrm{MEA}$ and $\mathrm{NO}_{3}$ (case $\mathrm{KNO} 3 \mathrm{M}$ ) did not affect the surface concentration pattern of amines. Using the wet scavenging rate of $\mathrm{SO}_{2}$ instead of $\mathrm{HNO}_{3}$ to describe the wet deposition of MEA (case WDEP) increased the maximum concentration slightly, by $0.9 \%$. The largest change of the maximum concentration was found when a different plume rise parameterization was applied. The maximum surface concentration of amines was only $26 \mathrm{ng} \mathrm{m}^{-3}$ when using the PVDI Plume option (case PLUME; Fig. 7b), a reduction by $60 \%$ compared to the baseline case. The PVDI Plume option entails a higher final plume rise, leading to lower surface concentrations in the vicinity of the CCP. The final plume rise for the stack configuration of this study $(60 \mathrm{~m}$ high stack, diameter of $7 \mathrm{~m}$, and exit velocity of $10 \mathrm{~m} \mathrm{~s}^{-1}$ ) calculated by PVDI Plume may be two to three times larger than the final plume rise calculated by NILU Plume for stable and unstable conditions. The maximum ground-level concentration decreases roughly proportional to the square of the effective emission height; thus an increase of the effective emission height from about $140 \mathrm{~m}$ to about $300 \mathrm{~m}$ - due to a three times larger final plume rise - could potentially cause a reduction of the maximum concentration by up to $78 \%$. The spatial distribution and maximum concentrations in the worst 
case using the PVDI Plume option were quite similar to the case PLUME, indicating that the local dispersion of emitted amines is mainly determined by the applied plume rise parameterization. Tests with a simple Gaussian plume model confirmed the high sensitivity of the ground-level concentrations of amines to the respective parameterization of plume rise, especially under neutral and moderately stable conditions (see Supplement Sect. S2, and Fig. S2).

Figure S8 in the Supplement shows the annual average air concentration of the sum of nitrosamines and nitramines, produced in the photochemical reactions of MEA and DEYA. In the maximum impact area, MEA-nitramine, DEYAnitramine, and DEYA-nitrosamine contributed 78, 14, and $7 \%$, respectively, to the sum concentration (baseline case). The reacted amount of MEA in the different cases was quantified in terms of concentration difference (in $\mathrm{ng} \mathrm{m}^{-3}$ ) between the chemically reactive MEA model species and a chemically inert, passive tracer emitted with the same rate and yearly amount as MEA. The reacted amount of $0.18 \mathrm{ng} \mathrm{m}^{-3}$ in the baseline case is only $0.3 \%$ of the maximum air concentration of MEA; thus chemical degradation has a marginal effect on the ground-level concentration of the amine in the vicinity of the CCP, as discussed above. July was the month with the highest photochemical activity in 2007 and the reacted amount of MEA was up to $2.0 \mathrm{ng} \mathrm{m}^{-3}$ in this month, dominating the annual average. Supplement Fig. S9 gives an overview of the spatial pattern of the reacted amount of MEA in the various cases.

In the baseline case and in the cases which use the plume rise option NILU Plume, the maximum surface air concentration of the sum of toxic products was located close to the $\mathrm{CCP}$ at a distance of $4 \mathrm{~km}$ to the west. The impacted area was about $20 \mathrm{~km}$ long and $10 \mathrm{~km}$ wide in a SE-NW direction due to dominant E-SE winds during the photochemical active period in July. From the CCP Mongstad stack, pollutants are injected into the second and third vertical layer of the EMEP model and presumably the plume is transported in these layers. In the third layer (184-324 m) at Mongstad, the winds from the $\mathrm{W}$ to $\mathrm{SW}$ had a somewhat higher frequency $(15 \%$ of the time) than the winds from the SE (7-12\% of the time; Supplement Fig. S10), but winds from the E-SE frequently had high wind speeds in July. Case KNO3M involves the additional reaction of $\mathrm{MEA}$ with $\mathrm{NO}_{3}$ radicals using a rate constant of $1.5 \times 10^{-13} \mathrm{~cm}^{3}$ molecule $\mathrm{e}^{-1} \mathrm{~s}^{-1}$. Compared to other sensitivity cases, the case $\mathrm{KNO} 3 \mathrm{M}$ had the highest reacted amount of MEA, $0.38 \mathrm{ng} \mathrm{m}^{-3}$. Reaction with $\mathrm{NO}_{3}$ occurs mainly during night-time resulting in a more uniform distribution of the sum of nitrosamines and nitramines (Supplement Fig. S8d), and a wider area with enhanced chemical turnover, extending from Mongstad to about $10 \mathrm{~km} \mathrm{NW}$ of the CCP. The $\mathrm{NO}_{3}$ reaction is relevant during most months of the year. The dispersion pattern of KNO3M is therefore impacted by the yearly average frequency of different wind directions.
In case PLUME which applies the plume rise parameterization PVDI Plume, MEA is injected into higher vertical layers and therefore the reacted amount in the vicinity of the CCP becomes negligible. Case PLUME showed the maximum impact area located 15-20 km SE of the CCP (Fig. S8b in the Supplement), and had the lowest maximum concentration of nitrosamines and nitramines. The main effect of the higher plume rise is the transport of emitted compounds out of the study area, effectively reducing the impact in the vicinity of the CCP. In the worst case where additional $\mathrm{NO}_{3}$ reaction is combined with the NILU Plume option (Fig. S8i in the Supplement) the main area of impact extends from Mongstad to about $20 \mathrm{~km} \mathrm{NW}$ of the CCP. In this area, the reacted amount of MEA is about two times higher than the maximum reacted amount in the baseline case. The increased impact is mainly a result of the relative high $\mathrm{NO}_{3}$ reactivity in late autumn and winter. The worst case run using PVDI Plume instead of NILU Plume resulted in a similar pattern but with, on average, $\sim 50 \%$ smaller air concentrations of the sum of nitrosamines and nitramines (Supplement Fig. S8j).

Table 6 provides an overview of the yearly average air ground-level concentrations of amines and toxic gas-phase products in the study grid of $40 \mathrm{~km} \times 40 \mathrm{~km}$ around CCP Mongstad. The maximum values in the study area of the sum of nitrosamines and nitramines in the sensitivity test range from 0.6 to $6.5 \mathrm{pg} \mathrm{m}^{-3}$, with the highest modelled concentrations in case YIELD in which the branching ratio $k_{1 \mathrm{a}} / k_{1}$ of the $\mathrm{H}$ abstraction at the $\mathrm{NH}_{2}$ group of the MEA molecule is doubled compared to the reference. Increasing the rate constant of the $\mathrm{MEA}+\mathrm{OH}$ reaction by $21 \%$ (case $\mathrm{KOHM}$ ) increased the maximum reacted amount and also the maximum concentration of MEA-nitramine almost linearly, by $19 \%$. The maximum sum concentration of nitrosamines and nitramines increased only by $15 \%$ since DEYA-nitramine and DEYA-nitrosamine production did not change. Case AQP which takes into account equilibrium partitioning of MEA to the aqueous phase shows the lowest maximum of the reacted amount for the studied cases, and a decrease of the sum of toxic oxidation products by $62 \%$ compared to the baseline case. Partitioning of MEA to the aqueous phase of low clouds effectively reduces photochemical production of nitrosamines and nitramines, because it reduces the fraction of MEA in the gas phase that is available for reaction with $\mathrm{OH}$.

Dry deposition contributed on average $40 \%$ to the total deposition of the sum of nitrosamines and nitramines inside the study grid. The relatively large contribution of dry deposition is in contrast to results from the "worst case scenario" study by Karl et al. (2011) who reported that the annual grid-averaged dry deposition flux of nitrosamines and nitramines was only about one-eighth of the annual wet deposition flux. The more important role of dry deposition in the present study is probably due to a more advanced description of the dry deposition process and less frequent precipitation in the WRF-EMEP model system, as will be discussed 
Table 6. Overview of results from the simulation runs. The grid maximum of the yearly average surface air concentration of amines (MEA + DEYA), sum of nitrosamines and nitramines, annual wet deposition flux, and drinking water concentration of sum nitrosamines and nitramines in the study area $40 \mathrm{~km} \times 40 \mathrm{~km}$ around CCP Mongstad. The grid mean of the yearly air concentrations is given in brackets. The relative change (in \%) of the max. total deposition of sum nitrosamines and nitramines and the relative change (in \%) of the max. drinking water sum concentration compared to the baseline case are also shown. Concentration sum and flux sum refer to the sum of all nitrosamines and nitramines. The maximum total deposition computed by the EMEP model was used to determine maximum drinking water concentration with the fugacity level III model. Dry and wet deposition fluxes were taken from the EMEP grid cell with the maximum total deposition. Safety limits set by the Norwegian Environment Agency are given in the last column.

\begin{tabular}{|c|c|c|c|c|c|c|c|c|c|c|}
\hline & BASE & PLUME & KOHM & KNO3M & YIELD & KNIM & AQP & WDEP & Worst & $\begin{array}{r}\text { Safety } \\
\text { limit }\end{array}$ \\
\hline $\begin{array}{l}\text { Grid max. (mean) surface air } \\
\text { concentration amines }\left(\mathrm{ng} \mathrm{m}^{-3}\right)\end{array}$ & $\begin{array}{r}64.9 \\
(6.52)\end{array}$ & $\begin{array}{r}25.9 \\
(3.49)\end{array}$ & $\begin{array}{r}64.8 \\
(6.52)\end{array}$ & $\begin{array}{r}64.7 \\
(6.34)\end{array}$ & $\begin{array}{r}64.9 \\
(6.52)\end{array}$ & $\begin{array}{r}64.9 \\
(6.52)\end{array}$ & $\begin{array}{r}65.0 \\
(6.54)\end{array}$ & $\begin{array}{r}65.5 \\
(6.65)\end{array}$ & $\begin{array}{r}64.7 \\
(6.33)\end{array}$ & - \\
\hline $\begin{array}{l}\text { Grid max. (mean) surface air } \\
\text { concentration sum }\left(\mathrm{pg} \mathrm{m}^{-3}\right)\end{array}$ & $\begin{array}{r}3.7 \\
(0.38)\end{array}$ & $\begin{array}{r}0.6 \\
(0.05)\end{array}$ & $\begin{array}{r}4.2 \\
(0.43)\end{array}$ & $\begin{array}{r}5.6 \\
(2.41)\end{array}$ & $\begin{array}{r}6.5 \\
(0.69)\end{array}$ & $\begin{array}{r}3.7 \\
(0.39)\end{array}$ & $\begin{array}{r}1.4 \\
(0.17)\end{array}$ & $\begin{array}{r}3.7 \\
(0.38)\end{array}$ & $\begin{array}{r}9.6 \\
(2.85)\end{array}$ & 300.0 \\
\hline $\begin{array}{l}\text { Grid max. total deposition flux } \\
\text { sum }\left(\mu \mathrm{g} \mathrm{m}^{-2}\right)\end{array}$ & 1.37 & 1.16 & 1.57 & 2.27 & 2.45 & 1.37 & 0.67 & 1.08 & 3.79 & - \\
\hline $\begin{array}{l}\text { Wet deposition flux sum at max. } \\
\text { location }\left(\mu \mathrm{g} \mathrm{m}^{-2}\right)\end{array}$ & 0.41 & 1.05 & 0.47 & 0.81 & 0.73 & 0.41 & 0.57 & 0.12 & 1.45 & - \\
\hline $\begin{array}{l}\text { Dry deposition flux sum at max. } \\
\text { location }\left(\mu \mathrm{g} \mathrm{m}^{-2}\right)\end{array}$ & 0.96 & 0.11 & 1.10 & 1.46 & 1.72 & 0.96 & 0.10 & 0.96 & 2.34 & - \\
\hline $\begin{array}{l}\text { Rel. change of max. total depo- } \\
\text { sition flux sum }(\%)\end{array}$ & 0 & -15 & +15 & +66 & +79 & $<1$ & -51 & -21 & +176 & - \\
\hline $\begin{array}{l}\text { Max. drinking water concentra- } \\
\text { tion sum }\left(\mathrm{ng} \mathrm{L}^{-1}\right)\end{array}$ & 0.08 & 0.07 & 0.10 & 0.13 & 0.15 & 0.08 & 0.04 & 0.07 & 0.22 & 4.0 \\
\hline $\begin{array}{l}\text { Rel. change of max. drinking } \\
\text { water conc. sum }(\%)\end{array}$ & 0 & -19 & +15 & +60 & +75 & $<1$ & -52 & -21 & +168 & - \\
\hline
\end{tabular}

in Sect. 3.7. In general, the location of the maximum deposition impact was found within $5 \mathrm{~km}$ of the CCP for the parameter variation cases where the total deposition maximum was dominated by dry removal whereas it was found in the region 15-20 km E-NE of the CCP for the cases where the total deposition maximum was dominated by wet removal. In the baseline case, dry deposition contributed $70 \%$ to the total deposition at the maximum impact location.

In the photochemically active month of July 2007, the model-predicted amount of rain was highest (ca. 240$310 \mathrm{~mm}$ ) in the chain of hills and mountains ca. $15 \mathrm{~km}$ to the east of Mongstad. In all simulated cases, the maximum impact from wet deposition occurred in the region $15-20 \mathrm{~km}$ E-NE of the CCP. Since this receptor region, the eastern part of the Fensfjorden-Austfjorden and the Masfjorden, is downwind of the CCP frequently during summer when W-NW winds are common, it can be expected that this is the highest impact area for wet deposition of nitrosamines and nitramines that form in the photo-oxidation of emitted amines. In the worst case, maximum annual deposition flux of the sum of nitrosamines and nitramines reached values of up to $3.8 \mu \mathrm{g} \mathrm{m}^{-2} \mathrm{yr}^{-1}$; about three times higher than in the baseline case (Fig. 8). Dry deposition contributed $70 \%$ to the deposition maximum located in close vicinity to the plant. When the plume rise parameterization PVDI Plume was used in the worst case, the resulting deposition maximum $\left(3.3 \mu \mathrm{g} \mathrm{m}^{-2} \mathrm{yr}^{-1}\right)$ was located approximately $15 \mathrm{~km}$ east of the plant (Fig. 8e), where dry deposition contributed only $9 \%$. The location of the maximum impact critically depends both on the description of the plume rise and of the dry/wet removal in the model.

The largest increase in a test case with variation of a single parameter was found for YIELD (Fig. 8f) with an increase of the deposition flux of the sum of nitrosamines and nitramines by $80 \%$ compared to the baseline case; this is due to a doubling of the branching ratio $k_{1 \mathrm{a}} / k_{1}$. Use of the wet scavenging rates of $\mathrm{SO}_{2}$ instead of the scavenging rates of $\mathrm{HNO}_{3}$ (WDEP) reduced the wet deposition flux by almost $70 \%$. In the EMEP model, the scavenging ratios of $\mathrm{SO}_{2}$ for both incloud and below-cloud scavenging are one-fifth of the scavenging ratios of $\mathrm{HNO}_{3}$. In WDEP, dry deposition was more important than wet deposition and the maximum of total deposition $\left(1.08 \mu \mathrm{g} \mathrm{m}^{-2} \mathrm{yr}^{-1}\right.$ ) was close to the plant (Fig. $8 \mathrm{~g}$ ).

Table 7 shows the effect on sum nitrosamine and nitramine when varying the selected parameters in the fugacity model. As expected, the hydrology of the system, here exemplified by the residence time of the water, has a large impact on the predicted concentrations. Varying the depth of the lake and the area has a similar effect on residence time and therefore also on concentrations in the water. Perhaps somewhat 
surprising is the negligible effect of changing the carbon content of both the soil and the sediment compartment in the system.

On the other hand, increasing the depth of the soil itself leads to a lower concentration of the compounds in the lake since more of the contaminants will be "stored" in the soil compartment. The explanation why the soil chemistry is not important, but the soil depth is, lies in the fact that most of the compound amount is associated with water, and increasing the depth of the soil also increases the volume of water in the soil compartment of the model. Increasing the degradation rates of the contaminants reduces the concentrations in the lake as expected. The sensitivity of the model parameters indicate that efforts should be made to have as accurate numbers as possible for the physical characteristics of the catchment and the degradation rates of the compounds.

\subsection{Mass balance of MEA}

The atmospheric MEA mass balance in the $200 \mathrm{~km} \times 200 \mathrm{~km}$ inner domain from the WRF-EMEP simulation for year 2007 was inspected in the baseline case. About half of the emitted amount of MEA $(40000 \mathrm{~kg})$ was transported out of the inner domain by diffusion and advection $(19800 \mathrm{~kg})$. Net transport out of the inner domain represented the major removal pathway of MEA. Recirculation of MEA from the intermediate domain $(10 \mathrm{~km}$ resolution), re-entering the inner domain, corresponded to about $2 \%$ of the total emitted amount. Dry deposition and wet deposition were both relevant for the removal and contributed 29 and $17 \%$, respectively. The loss of MEA by reaction with $\mathrm{OH}$ radicals contributed only $5 \%(\sim 2100 \mathrm{~kg})$. The relatively small contribution of chemical degradation also explains why groundlevel MEA concentrations were not sensitive to a change of the rate constant by $21 \%$. On the other hand, production of MEA-nitramine increased almost linearly with the increasing MEA $+\mathrm{OH}$ rate constant. The majority of the chemical turnover in the MEA $+\mathrm{OH}$ reaction leads to the production of carbonylic products, which are not further studied here. A study of the complete product spectrum from the atmospheric oxidation of MEA for the environmental conditions at Mongstad is the subject of our follow-up work (Karl et al., 2014).

\subsection{Removal of nitramines and nitrosamines}

Reducing the rate constant of the reaction between MEAnitramine and $\mathrm{OH}$ by a factor of $23 \mathrm{had}$ a negligible effect on the sum concentration (see Table 6), indicating that the removal of nitramines by $\mathrm{OH}$ reaction is not a relevant loss process in the $40 \mathrm{~km} \times 40 \mathrm{~km}$ study grid. However, analysis of the atmospheric loss pathways of the sum of nitrosamines and nitramines in the total inner domain $(200 \mathrm{~km} \times 200 \mathrm{~km})$ revealed that chemical degradation constituted $21 \%$ of the total loss in the atmosphere (Fig. 9a). Due to the large con- tribution of MEA-nitramine to the sum of nitrosamines and nitramines in the atmosphere, the reaction of MEA-nitramine with $\mathrm{OH}$ is the most relevant loss reaction of the sum of toxic products. DEYA-nitrosamine, which is lost rapidly by photolysis in sunlight, certainly has a higher fractional loss by chemical degradation but its contribution to the atmospheric sum concentration was minor. Net transport of nitrosamines and nitramines out of the inner domain contributed another $20 \%$ to the total loss. Dry and wet deposition were equally important removal processes, each contributing one-third to the total loss.

Degradation of nitrosamines and nitramines in water was the dominant removal pathway for these compounds (Fig. 9b) in a generic lake receiving maximum deposition flux (dry and wet). Minor loss processes were run-off (10\% of total loss) and degradation in soil (15\% of total loss). Partitioning of nitrosamines and nitramines to sediments was negligible.

\subsection{Comparison with TAPM simulation results}

Monthly average air concentration, dry deposition, and wet deposition of an inert tracer emitted from the CCP with a unity emission rate $\left(1 \mathrm{~g} \mathrm{~s}^{-1}\right)$ from the baseline case with the WRF-EMEP model system were compared to the results of the previous "worst case scenario" study using the TAPM model (Karl et al., 2011). The comparison is summarized in Table S7 in the Supplement. The maximum monthly mean air concentration was in the range of $20-140 \mathrm{ng} \mathrm{m}^{-3}$ and $30-140 \mathrm{ng} \mathrm{m}^{-3}$ for WRF-EMEP and TAPM, respectively, in the $40 \mathrm{~km} \times 40 \mathrm{~km}$ study area. Yearly average air concentrations showed a similar spatial distribution with a centre 5$10 \mathrm{~km} \mathrm{~N}-\mathrm{NW}$ of the CCP, and a second centre 5-10 km SE of the CCP (Fig. 10a-b), indicating that dispersion by the main wind direction on a yearly average was reproduced in a similar way. The TAPM simulation had a wider impact area with concentrations $>10 \mathrm{ng} \mathrm{m}^{-3}$ and a lower maximum $\left(30 \mathrm{ng} \mathrm{m}^{-3}\right.$ instead of $45 \mathrm{ng} \mathrm{m}^{-3}$ ) probably due to a higher plume rise. A comparison of the monthly average air concentrations for July 2007 shows similar impact areas (Fig. 10c-d), but the maximum close to the source was lower in the TAPM simulation (TAPM: $48 \mathrm{ng} \mathrm{m}^{-3}$, WRF-EMEP: $86 \mathrm{ng} \mathrm{m}^{-3}$ ).

The first vertical layer, from which ground-level concentrations were taken, is at ca. $90 \mathrm{~m}$ in the EMEP model while it is only at $10 \mathrm{~m}$ in TAPM. The reason for the (yearly average) narrower dispersion in the EMEP model might be the advection from a point source with grid-cell size $(2 \mathrm{~km} \times 2 \mathrm{~km})$. However, different parameterizations of plume rise and of dry deposition in the two models, together with more frequent occurrence of moderately stable cases in the TAPM simulation (which uses different meteorological data) are also plausible explanations for different maximum concentrations and different extents of the impact area. 

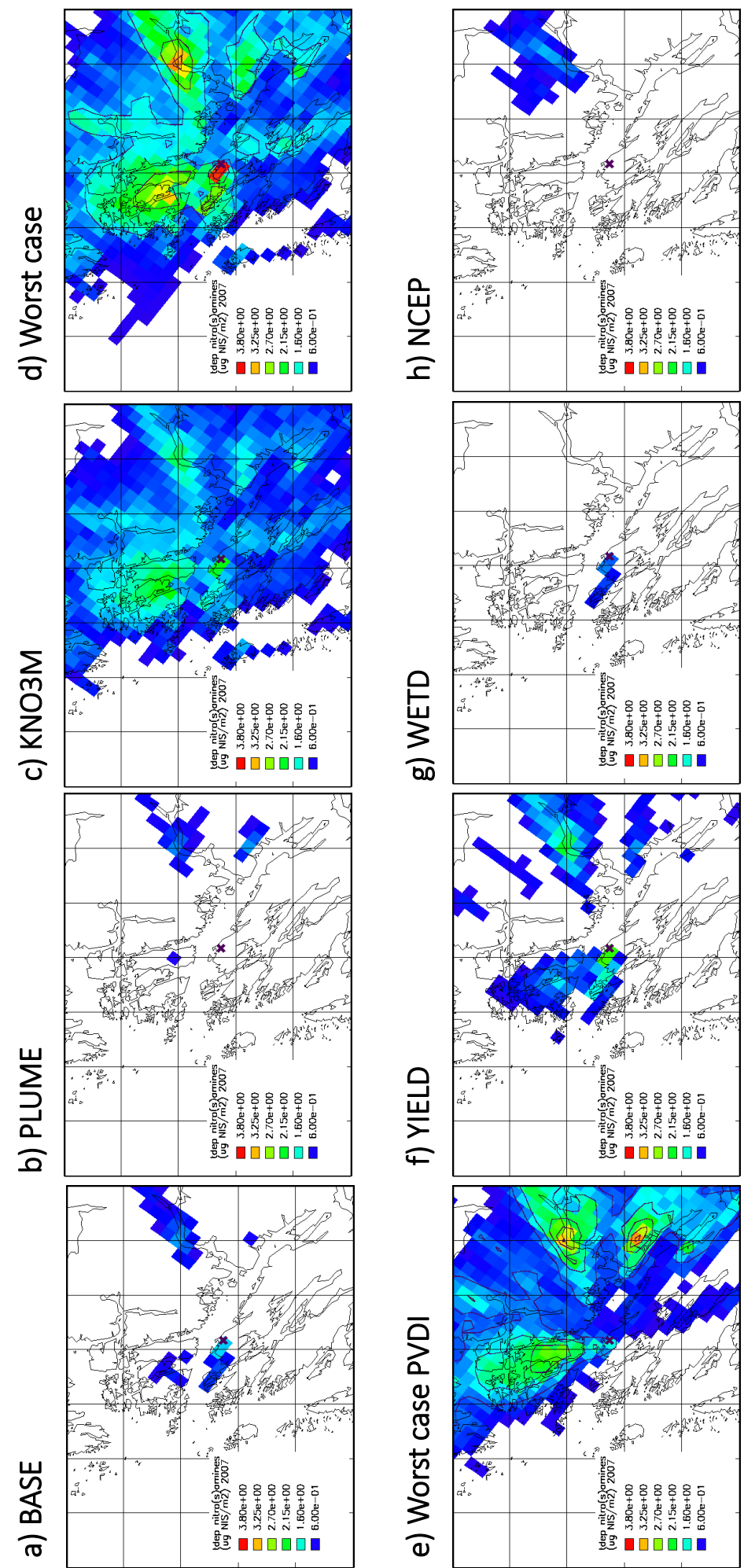

Figure 8. Total deposition flux (dry and wet deposition) of the sum of nitrosamines and nitramines (in $\mu \mathrm{g} \mathrm{m}^{-2}$ ). Spatial distribution of the annual average (year 2007) computed by WRF-EMEP in the (a) baseline case (BASE), (b) case PLUME using the PVDI Plume parameterization, (c) case $\mathrm{KNO} 3 \mathrm{M}$ which includes the reaction of MEA with $\mathrm{NO}_{3}$ radicals, (d) worst case using the parameter values given in Table 5, (e) worst case with PVDI Plume instead of NILU Plume, (f) case YIELD, (g) case WETD, and (h) baseline case using NCEP FNL meteorological data. Values below the smallest legend entry are not shown. The location of CCP Mongstad is marked by a purple X. The grid cells divided by black lines illustrate an extent of $10 \mathrm{~km} \times 10 \mathrm{~km}$. All plots have the same concentration scale. 
a)

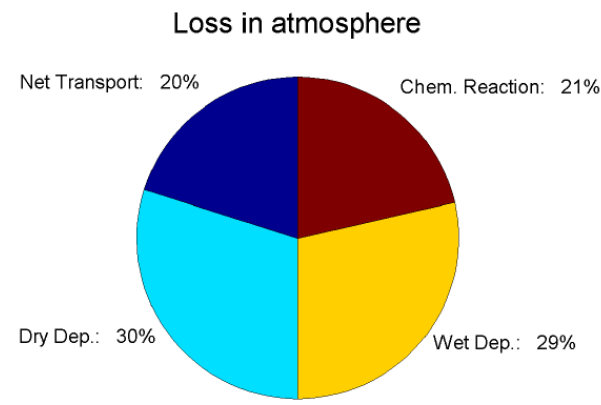

b)

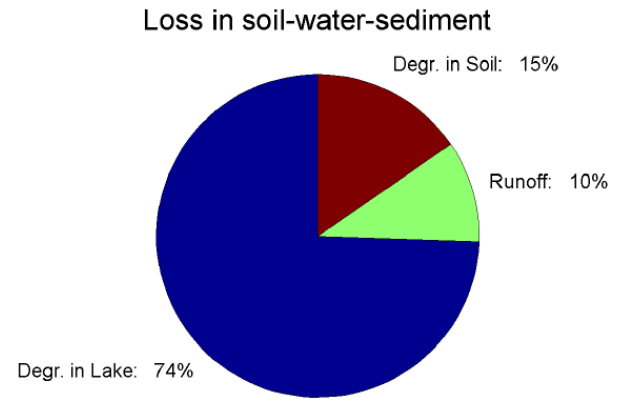

Figure 9. Percentage removal pathways of the sum of nitrosamines and nitramines (a) in the atmosphere in the $200 \mathrm{~km} \times 200 \mathrm{~km}$ inner domain from the WRF-EMEP simulation and (b) in the soil/water/sediment compartments at the location of maximum deposition calculated by the fugacity level III model. Results are from the baseline simulation.

Table 7. Results of the fugacity model given variations in several parameters. Shown are simulated maximum concentrations of the sum of nitrosamine and nitramines ( $\mathrm{n} \mathrm{L}^{-1}$ ) in a generic lake. For each case (see Table 4) the predicted sum of contaminants are given for the high (top) and low (bottom) parameter value settings or for the single changed parameter set (degradation rates and worst case). Case "Worst" uses the worst case parameters for soil/water/sediment fate (Table 5). All fugacity model calculations are based on the WRF-EMEP baseline case (BASE) results.

\begin{tabular}{rrrrrrrrrr}
\hline Base & $\begin{array}{r}\text { Hyd } \\
\text { Dep }\end{array}$ & $\begin{array}{r}\text { Hyd } \\
\text { Area }\end{array}$ & $\begin{array}{r}\text { Soil } \\
\text { Dep }\end{array}$ & $\begin{array}{r}\text { Chem } \\
\text { Soil }\end{array}$ & $\begin{array}{r}\text { Chem } \\
\text { Sed }\end{array}$ & $\begin{array}{r}\text { DegRate } \\
\text { MNA }\end{array}$ & $\begin{array}{r}\text { DegRate } \\
\text { NDMA }\end{array}$ & Worst & $\begin{array}{r}\text { Safety } \\
\text { limit }\end{array}$ \\
\hline \multirow{2}{*}{0.082} & 0.146 & 0.145 & 0.087 & 0.082 & 0.082 & 0.009 & 0.074 & 0.253 & 4.0 \\
& 0.044 & 0.044 & 0.074 & 0.082 & 0.082 & & & & \\
\hline
\end{tabular}

Maximum monthly dry deposition of the inert tracer was in the range of $0.9-4.8 \mathrm{mg} \mathrm{m}^{-2}$ and $0.1-1.1 \mathrm{mg} \mathrm{m}^{-2}$ for WRF-EMEP and TAPM, respectively, with, on average, seven times higher values in the WRF-EMEP simulation. In general, the dry deposition maximum simulated by WRFEMEP is centred close to the CCP and shows a similar spatial distribution as the mean air concentration. TAPM results for dry deposition show a maximum at a distance of $20 \mathrm{~km}$ $\mathrm{E}$ of the CCP in the mountains. The maximum monthly wet deposition flux was in the range of $0.4-2.2$ and 2.2$6.0 \mathrm{mg} \mathrm{m}^{-2}$ for WRF-EMEP and TAPM, respectively, with, on average, three times lower values in the WRF-EMEP simulation. The wet deposition maximum simulated by WRFEMEP is located very close to the CCP, while the maximum simulated by TAPM is ca. $20 \mathrm{~km}$ to the east in the mountains. Total precipitation amounts simulated by TAPM were as much as twice as high as amounts observed in the mountains. We therefore considered the wet deposition maximum in the mountains computed by TAPM to be not reliable. On the other hand, TAPM results showed a second maximum area ca. $5 \mathrm{~km} \mathrm{NE}$ of the CCP, where predicted precipitation agreed with station observations. For the comparison, maximum values were only taken from the second maximum area.

Possible reasons for the location of maximum dry deposition and wet deposition fluxes of the inert tracer at 20$30 \mathrm{~km} \mathrm{E}$ of the CCP as simulated by the TAPM model - compared to the much closer location in the WRF-EMEP model - include the obviously too high frequency and amount of precipitation in the mountains in the TAPM simulation; different underlying land use information, different treatment of scavenging by dry and wet deposition, and different vertical stratification of the models. In the TAPM simulation, the Lagrangian plume sub-grid model was applied in order to account for near-source effects, including gradual plume rise and near-source dispersion. Deposition processes in the TAPM model were treated on the Eulerian grid, while they were neglected in the sub-grid model.

\subsection{Meteorological data source}

Dispersion of emitted amines in the baseline case showed little change when the meteorological data from NCEP FNL was applied as expected due to the high similarity of the annual wind roses obtained from WRF model runs with ECMWF and NCEP FNL meteorology (Supplement Fig. S4a-c). The maximum modelled surface concentration of amines from the baseline case run with NCEP FNL meteorological data in the study area $\left(62 \mathrm{ng} \mathrm{m}^{-3}\right)$ was located at the same place as in the run with ECMWF data. However, the impact area of toxic gas-phase products was different. In the calculation with NCEP FNL, the impacted area was found $10-20 \mathrm{~km} \mathrm{NE}$ of the CCP, with a maximum concentration for the sum of nitrosamines and nitramines close to $1 \mathrm{pg} \mathrm{m}^{-3}$ (Supplement Fig. S8k). The reason for the different impact area, compared to the baseline case run with ECMWF data, might be differences in the prevailing wind 
a)

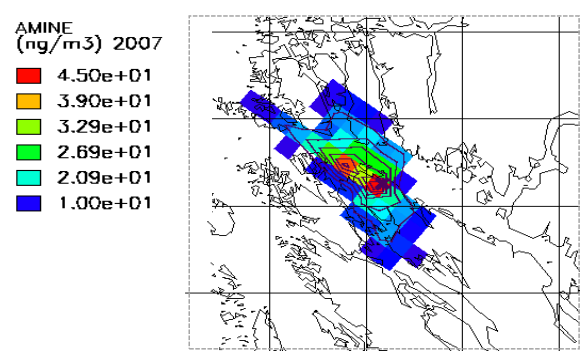

c)

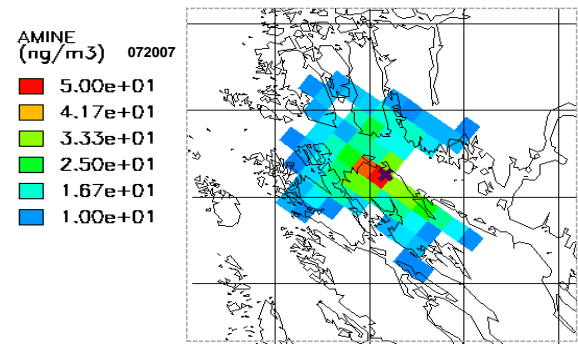

b)

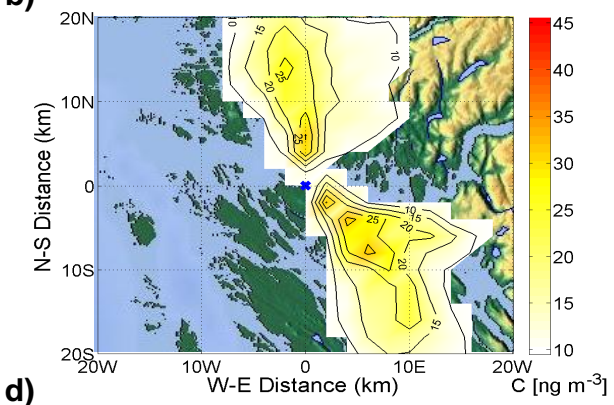

d)

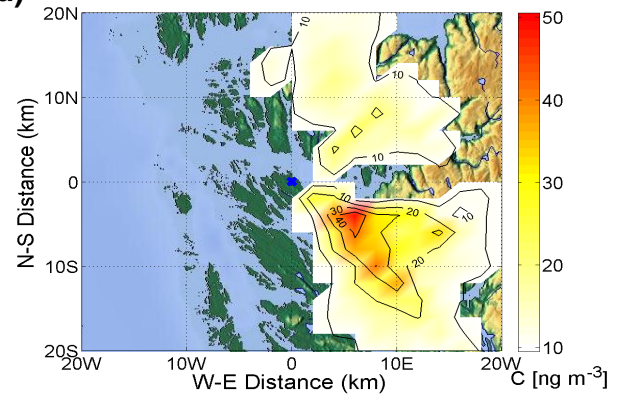

Figure 10. Comparison of ground-level air concentration of a chemically inert tracer (in $\mathrm{ng} \mathrm{m}^{-3}$ ) emitted from the $\mathrm{CCP}$ with unity emission rate (of $1 \mathrm{~g} \mathrm{~s}^{-1}$ ): (a) annual average (year 2007) from the WRF-EMEP simulation (reference scenario), (b) annual average (year 2007) from the TAPM simulation of the worst case scenario study by Karl et al. (2011), (c) monthly average for July 2007 from the WRF-EMEP simulation (reference scenario), and (d) monthly average for July 2007 from the TAPM simulation of the worst case scenario study by Karl et al. (2011). The same concentration scale is used for the corresponding maps. Concentration values below $10 \mathrm{ng} \mathrm{m}^{-3}$ are not shown. The location of CCP Mongstad is marked by a blue or purple X. The grid cells divided by black lines illustrate an extent of $10 \mathrm{~km} \times 10 \mathrm{~km}$.

direction during the photochemically active month July, with more frequent SW winds in the NCEP FNL meteorological data (Supplement Fig. S4f vs. S4e). The maximum wet deposition flux of the sum of nitrosamines and nitramines was $1.04 \mu \mathrm{g} \mathrm{m}^{-2} \mathrm{yr}^{-1}$ when using NCEP FNL meteorological data (Fig. 8h), only slightly higher than in the baseline case with ECMWF meteorological data. As in the other modelled cases, the maximum impact from wet deposition occurred in the region $15-20 \mathrm{~km}$ E-NE of the CCP. The predicted precipitation amount for July in this area was between 150 and $250 \mathrm{~mm}$. Brekke is the met station closest to this impact area. Precipitation amount time series at Brekke simulated using ECMWF meteorological data is in quite close agreement with the observed time series in summer, while the simulation using NCEP FNL underestimates the observed amounts by ca. $50-80 \%$ (Fig. 4). In simulations with the two meteorological data sets for July, the hills and mountains along the eastern part of the Fensfjorden-Austfjorden and the Masfjorden received the highest precipitation amounts (up to $380 \mathrm{~mm}$ ) inside the study area.

\section{Discussion}

The performance of the WRF-EMEP model system for use as a tool for impact assessment of amine emission from postcombustion capture was evaluated in this study. We applied the new modelling framework to a hypothetical CCP located at Mongstad, on the west coast of Norway, as a case study. Temperature and frequencies of wind direction and wind speed predicted by the WRF model using ECMWF data were in good agreement with observations from meteorological stations in the region. Fast small-scale variations of the observed $\mathrm{NO}_{2}$ concentration at Mongstad were not captured by the EMEP model. Observed $\mathrm{NO}_{2}$ peaks were likely a result of short-term variation in the local emissions from the industrial area, which is not represented in the model. Plume rise from the CCP point source was implemented in the EMEP model for calculation of the vertical emission profile of amines online with the local meteorology. However, accurate treatment of injection height is limited by the relative coarse vertical resolution of the EMEP model. A refinement of the vertical structure of the EMEP model is currently under development.

A condensed atmospheric reaction scheme for amines leading to the production of nitrosamines and nitramines was included in the EMEP model, for the first time allowing for prediction of time-dependent concentrations of nitrosamines and nitramines in air and deposition. The study showed that amine emissions were spread over a relatively wide region. The particle formation potential of CCP amine emission was not assessed. Losses of gas-phase alkanol amines due to formation of low vapour-pressure amine salts might be significant, in particular close to point sources 
(Nielsen et al., 2012b). For example, alkyl ammonium nitrates exhibit comparable stability to that of ammonium nitrate under atmospheric conditions (Salo et al., 2011). However, the impact of gas-to-particle conversion of the emitted amines is difficult to quantify because it depends on the magnitude of sources and sinks of the acids (e.g. nitric acid), the amounts of other amines or ammonia present that compete for available acids, and the amine salt equilibrium constants which are not known for many amines.

A fugacity level III model was coupled to the EMEP model in offline mode to simulate the steady-state distribution of nitrosamines and nitramines in an evaluative environment. We opted to use a generic catchment structure to arrive at likely concentrations of the contaminants in sources of drinking water since a more detailed local analysis would require a large amount of more precise measurement of physical and chemical characteristics of a chosen focal catchment. Though fairly advanced methods for sensitivity and uncertainty estimation exist for fugacity models (see e.g. MacLeod et al., 2002; Saloranta et al., 2007), they require measurements of the studied compounds in the environment (after exposure) and a sufficient amount of environmental data to calibrate the models. Both requirements are not fulfilled in the current context.

When humid Atlantic air meets the hill chain in the east of Mongstad, orographic rainfall is difficult to predict with numerical models. The WRF model driven by ECMWF meteorology copes quite well with this situation and the westeast gradient of precipitation amount is reproduced in a realistic manner. However, the average precipitation amount, and the rainfall frequency in July over the flat terrain in the coastal area around Mongstad, is underestimated by WRF. Increasing the precipitation amount, but not the frequency, would lead to dilution of the compounds and proportionally decreasing their concentration in wet deposition. Higher precipitation frequency along the trajectory from the CCP to the east would result in an impact area closer to the CCP, but since the yearly average timescale for chemical reaction of the amine (about $3 \mathrm{~h}$ ) is longer than the timescale for transport (less than $1 \mathrm{~h}$ ), the maximum wet deposition would decrease. On the other hand, applying a more realistic precipitation frequency in July everywhere in the coastal part of the study area could increase wet deposition flux in the vicinity of the plant by a factor of $2-3$. We conclude that the computed deposition fluxes of the sum of nitrosamines and nitramines have an additional uncertainty of a factor of 2 due to underestimated frequency and amount of precipitation.

The "worst case scenario" by Karl et al. (2011) aimed to estimate the maximum tolerable amine emission from postcombustion in order to avoid adverse effects on aquatic environments and human health according to the precautionary principle. This involved several conservative assumptions about the environmental fate of amines and their oxidation products, such as instant conversion of emitted amines into nitramines and nitrosamines, and the non-degradability of the toxic compounds in air, water, and soil. Karl et al. (2011) applied a constant conversion yield of $1 \%$ of the total emitted amine (MEA) amount implying that MEA-nitramine was directly emitted from the CCP stack. Based on this, the calculated maximum yearly deposition flux of MEAnitramine was $460 \mu \mathrm{g} \mathrm{m}^{-2}$. For comparison, the calculated total conversion yield for the WRF-EMEP simulation was $0.015 \%$, about $1 / 70$ of the worst case conversion. Dividing the worst case deposition of $460 \mu \mathrm{g} \mathrm{m}^{-2}$ by 70 results in a deposition flux of $6.6 \mu \mathrm{g} \mathrm{m}^{-2}$; a factor of 1.7 higher than the deposition $\left(3.8 \mu \mathrm{g} \mathrm{m}^{-2}\right)$ in the current atmospheric worst case using WRF-EMEP. In total, the modelled deposition flux maximum is about $1 / 120$ of the previous estimate by Karl et al. (2011), mainly due to detailed treatment of the production of MEA-nitramine in the atmospheric oxidation of MEA and the lower rainfall amount and frequency in the WRF-EMEP model system.

Steady-state drinking water concentration of the sum of nitrosamines and nitramines determined by the fugacity model considers degradation of these compounds in soil and water. Loss by run-off is only $10 \%$ in the present study, implying a 10 times longer retention time in the lake than in the study by Karl et al. (2011). Increased retention time in turn leads to increased degradation of the compounds in lake water. The drinking water concentration in the current worst case is roughly 10 times lower than the MEA-nitramine drinking water concentration calculated in the study by Karl et al. (2011), which did not consider degradation in soil and water.

In a recent study by de Koeijer et al. (2013) on the health risk of amine emissions in the air from the TCM $\left(\mathrm{CO}_{2}\right.$ Technology Centre Mongstad) plant, an attempt was made to include a simplified treatment of amine chemistry by calculating the average chemical conversion along the trajectory of maximum concentrations from plant to area of maximum impact. In that study a constant yield of less than $0.3 \%$ for MEA-nitramine in the reaction of MEA with $\mathrm{OH}$ was used. The conversion applied by de Koeijer et al. (2013) is thus at most one-third of the conversion as computed by WRFEMEP model system, which takes into account the spatial and temporal variability of levels of $\mathrm{OH}, \mathrm{NO}$, and $\mathrm{NO}_{2}$.

Additional sources of nitrosamines and nitramines, such as the direct emission of these compounds from the CCP, were not considered in this study. Reliable estimates on the amount of nitrosamines directly emitted to atmosphere are necessary to enable the environmental impact assessment of commercial-scale post-combustion (Reynolds et al., 2012). Actual human and environmental exposures to nitrosamines and nitramines are likely to be higher than estimated here due to natural background levels. In a baseline study for TCM, background air concentrations of 5-30 $\mathrm{ng} \mathrm{m}^{-3}$ of dimethylamine were reported (Tønnesen et al., 2011). The corresponding nitrosamine, NDMA, was not found in the air samples above the detection limit of the method $\left(10 \mathrm{pg} \mathrm{m}^{-3}\right)$. We expect that further improvement of the analytical methods for determination of nitrosamines and nitramines in air will 
reveal measurable concentrations. Measurements of amines in the plume and surroundings of an operative CCP are essential for the further evaluation of the WRF-EMEP system.

Degradation rates for nitrosamines and nitramines in soil and water are poorly known, yet the sensitivity trials show that the values chosen for these have a strong influence on the simulated final concentrations of these compounds in the lake water. Several studies investigated the degradation rates of various nitrosamines in soils in conjunction with use of wastewater treated with chloro compounds for recharge or irrigation purposes (Kaplan and Kaplan, 1985; Zhou et al., 2005; Yang et al., 2005; Drewes et al., 2006). The results from these and other studies indicate half lives of 1-22 days, with microbial activity being the dominant mechanism for degradation. In surface waters, photo-oxidation of nitrosamines is an important mechanism, while microbial activity appears to be less important (Plumlee and Reinhard, 2007). Yang et al. (2005) conclude that NDMA will have longer persistence and increased leaching in soils in areas with sparse vegetation, low organic matter content, and thus limited microbial activity. Such soils are typical for the Mongstad area of our study.

Consideration of amine oxidation by $\mathrm{NO}_{3}$ radicals increased the grid maximum of the yearly average surface concentration of the sum of nitrosamines and nitramines by $50 \%$ in our simulations. $\mathrm{NO}_{3}$ is the predominant nocturnal oxidant and the $\mathrm{NO}_{3}$ reaction takes place throughout the year, leading to a more uniform spatial distribution. The annual average concentrations of $\mathrm{OH}$ and $\mathrm{NO}_{3}$ computed for the year 2007 at the location of Hamna ( $3 \mathrm{~km}$ distant from Mongstad) by the WRF-EMEP model system are $8.9 \times 10^{5}$ molecules $\mathrm{cm}^{-3}$ and $1.2 \times 10^{8}$ molecules $\mathrm{cm}^{-3}$, respectively. With $k\left(\right.$ amine $\left.+\mathrm{NO}_{3}\right)$ of the order of $10^{-13} \mathrm{~cm}^{3}$ molecule $\mathrm{s}^{-1} \mathrm{~s}^{-1}$, and $k($ amine $+\mathrm{OH})$ of the order of $10^{-11} \mathrm{~cm}^{3}$ molecule $\mathrm{e}^{-1} \mathrm{~s}^{-1}$, the atmospheric amine removal rate by $\mathrm{NO}_{3}$ radicals will be approximately equal to the removal rate by $\mathrm{OH}$ radicals. Only a few smog chamber studies have looked into the kinetics and products from $\mathrm{NO}_{3}$ oxidation (Malloy et al., 2009) and amine reactions with $\mathrm{NO}_{3}$ are not well understood (Price, 2010). Based on proton transfer reaction mass spectrometry, detection of gas-phase compounds of the reaction between secondary aliphatic amines and the $\mathrm{NO}_{3}$ radical, Price (2010) proposed the formation of nitramines by $\mathrm{H}$ abstraction at the $\mathrm{NH}$ group and subsequent reaction of the resulting $\mathrm{N}$-amino radical with $\mathrm{NO}_{2}$ to explain high abundance of nitramines in the experiments.

\section{Conclusions}

The WRF-EMEP model system, which combines the WRF numerical weather prediction model with the EMEP MSCW chemical transport model, was modified to include treatment of atmospheric chemistry of amines and plume rise to address uncertainties in the environmental impact assessment of post-combustion $\mathrm{CO}_{2}$ capture with amine technology. The meteorological data of air temperature, wind speed, and wind direction calculated by the WRF model on $2 \mathrm{~km}$ horizontal resolution compared well with observed meteorological data in the region of Bergen at the west coast of Norway. The frequency and amount of precipitation due to orographic rain at the mountain chain ca. 10-20 km east of Mongstad was underestimated by the WRF model, causing an additional uncertainty of modelled deposition fluxes of nitrosamines and nitramines by a factor of 2 . It was beyond the scope of this work to study the impact of the year-to-year variation in meteorology; however, the selected baseline year 2007 is rather representative for the meteorological conditions of the region.

WRF-EMEP reproduced the photochemical reactivity in the atmosphere which is of prime importance for the simulation of amine degradation by $\mathrm{OH}$ radicals. The modelled summertime $24 \mathrm{~h} \mathrm{OH}$ concentration average was in good agreement with previous box model studies and the atmospheric production yield of MEA-nitramine was in the range reported from photo-oxidation experiments in EUPHORE. Future modifications of the EMEP model should take into account particle formation from amines as this might be a significant loss process close to the point source. The sensitivity analysis of the EMEP model strongly suggests that oxidation of amines by $\mathrm{NO}_{3}$ radicals is of importance. Currently only one study (Price, 2010) has qualitatively addressed nitramine formation in the oxidation of amines by $\mathrm{NO}_{3}$ radicals.

The location of the maximum deposition impact from the plant showed considerable spatial variability depending on the treatment of plume rise, characterization of dry and wet deposition, and the meteorological input data on wind speed and direction. The scavenging properties of amines have not been studied but the use of $\mathrm{NH}_{3}$ to represent dry removal and the use of $\mathrm{HNO}_{3}$ to represent wet removal in the EMEP model appears to be a plausible approximation. In contrast to the highly soluble nitrosamines and nitramines forming in the oxidation of alkanolamine, the solubility of the analogous alkyl compounds may be limited due to their lower Henry's law constants. Dry removal of nitrosamines and nitramines has been neglected in previous environmental impact assessments and more research on the scavenging properties of these compounds is needed.

The fugacity level III model is a useful tool for quantifying the fate of a substance and for predicting concentrations to which organisms, including humans, are exposed. Our sensitivity analysis of the fugacity model indicates that catchment characteristics and chemical degradation rates are among the important factors for determining concentrations of nitramines and nitrosamines (Table 7). More research on degradation rates of nitramines in soil and water is needed. The coupled model chain of the WRF-EMEP system and the fugacity model proved to be well suited for the prediction of yearly average ground-level air and drinking water concentrations of the sum of nitrosamines and nitramines, the two 
major human health risk endpoints related to amine-based $\mathrm{CO}_{2}$ capture.

This study for a full-scale post-combustion $\mathrm{CO}_{2}$ capture plant based on amine technology shows that realistic emissions result in levels of the sum of nitrosamines and nitramines in ground-level air $\left(0.6-10 \mathrm{pg} \mathrm{m}^{-3}\right)$ and drinking water $\left(0.04-0.25 \mathrm{ng} \mathrm{L}^{-1}\right)$ downwind the CCP not exceeding the current safety guideline for human health by the Norwegian Environment Agency. A number of complicating factors could increase the health risk.

There are about 5000 large point sources (each emitting more than $0.1 \mathrm{Mt}$ of $\mathrm{CO}_{2}$ per year) for electricity power generation using fossil fuels worldwide which could be retrofitted using amine-based post-combustion. IPCC (2005) estimated that $30-60 \%$ of the $\mathrm{CO}_{2}$ emissions from electricity generation can be captured. National plans for building carbon capture and storage (CCS) infrastructure exist in EU member states (e.g. in the UK), Canada, USA, Australia and China. Several post-combustion pilot plants and large-scale demonstration plants are operative in Europe and in the USA (Esbjerg, Denmark; Karlshamn, Sweden; SCCS Edinburgh, Scotland, UK; Brindisi, Italy; Plant Barry, Alabama, USA); several full-scale plants or near full-scale plants are planned (Peterhead, Scotland, UK; ArcelorMittal Florange, France; Porto Tolle, Italy; WA Parish, Texas, USA; Samcheok City, South Korea); and one full-scale CCP to capture $1 \mathrm{Mt} \mathrm{CO}_{2}$ per year is currently being build in Canada (Boundary Dam, Saskatchewan). A national or transnational plan on CCS infrastructure building might require the installation of several commercial-scale CCP in one region, since most fossil fuel power plants are concentrated in the proximity of major industrial and urban regions. According to our study, building a CCP within a distance of 100-200 km downwind of an existing CCP will cause interferences, and amine emissions released from the neighbouring plant will add to the chemically produced nitrosamines and nitramines in the surroundings of the existing CCP. Such a scenario illustrates the possible complexity arising from increased use of post-combustion capture, and the need for advanced model tools such as the coupled WRF-EMEP and fugacity model system presented here.

\section{The Supplement related to this article is available online at doi:10.5194/acp-14-8533-2014-supplement.}

Acknowledgements. Special thanks to H. D. van der Gon for granting permission to make use of the fine-scale emission data developed by TNO within the MACC project and to Bertrand Bessagnet (INERIS) for providing the emission data set. D. Tønnesen (NILU) is thanked for providing hourly air quality of Hamna and Leirvåg station. We thank the Notur infrastructure of UNINETT Sigma for allocation of CPU resources under project
NN9257K. Evaluation of the WRF-EMEP model system with local meteorology and air quality observational data was performed in the framework of the technology qualification of amines for the $\mathrm{CO}_{2}$ Capture Mongstad Project (CCM) funded by the Norwegian government through Statoil Petroleum AS and Gassnova SF. We acknowledge financial support from the Research Council of Norway, Statoil Petroleum AS, Shell, and Vattenfall under project 199874 (ExSIRA, Part C). The authors also thank NILU for additional financial support.

Edited by: T. Karl

\section{References}

Aas, W., Tsyro, S., Bieber, E., Bergström, R., Ceburnis, D., Ellermann, T., Fagerli, H., Frölich, M., Gehrig, R., Makkonen, U., Nemitz, E., Otjes, R., Perez, N., Perrino, C., Prévôt, A. S. H., Putaud, J.-P., Simpson, D., Spindler, G., Vana, M., and Yttri, K. E.: Lessons learnt from the first EMEP intensive measurement periods, Atmos. Chem. Phys., 12, 8073-8094, doi:10.5194/acp12-8073-2012, 2012.

Angove, D., Azzi, M., Tibbett, A., and Campbell, I.: An investigation into the photochemistry of monoethanolamine (MEA) in $\mathrm{NO}_{\mathrm{x}}$. in: Recent Advances in Post-Combustion $\mathrm{CO}_{2}$ Capture Chemistry, ACS Symposium Series, Washington, DC, vol. 1097, chap. 14, 265-273, 2012.

Berge, E. and Jakobsen, H. A.: A regional scale multi-layer model for the calculation of long-term transport and deposition of air pollution in Europe, Tellus, 50, 205-223, 1998.

Briggs, G. A.: Plume Rise, US Atomic Energy Commission, Springfield, USA, 1-81, 1969.

Briggs, G. A.: Some recent analyses of plume rise observation, in: Proceedings of the Second International Clean Air Congress, edited by: Englund, H. M. and Berry, W. T., Academic Press, Washington, USA, 6-11 December 1970, 1029-1032, 1971.

Briggs, G. A.: Plume rise predictions, in: Lectures on Air Pollution and Environmental Impact Analysis, edited by: Haugen, D. A., Amer. Meteor. Soc., Boston, MA, 59-111, 1975.

California EPA: Public Health Goal for N-nitrosodimethylamine in Drinking Water, California Environmental Protection Agency, Pesticide and Environmental Toxicology Branch, available at: http://oehha.ca.gov/water/phg/pdf/122206NDMAphg.pdf (last access: 29 June 2014), 2006.

Colette, A., Granier, C., Hodnebrog, Ø., Jakobs, H., Maurizi, A., Nyiri, A., Bessagnet, B., D’Angiola, A., D’Isidoro, M., Gauss, M., Meleux, F., Memmesheimer, M., Mieville, A., Rouïl, L., Russo, F., Solberg, S., Stordal, F., and Tampieri, F.: Air quality trends in Europe over the past decade: a first multi-model assessment, Atmos. Chem. Phys., 11, 11657-11678, doi:10.5194/acp11-11657-2011, 2011.

Dai, N., Shah, A. D., Hu, L., Plewa, M. J., McKague, B., and Mitch, W. A.: Measurement of nitrosamine and nitramines formation from $\mathrm{NO}_{\mathrm{x}}$ reactions with amines during amine-based carbon dioxide capture for postcombustion carbon sequestration, Environ. Sci. Technol., 46, 9793-9801, 2012.

Dee, D. P., Uppala, S. M., Simmons, A. J., Berrisford, P., Poli, P., Kobayashi, S., Andrae, U., Balmaseda, M. A., Balsamo, G., Bauer, P., Bechtold, P., Beljaars, A. C. M., van de Berg, L., Bidlot, J., Bormann, N., Delsol, C., Dragani, R., Fuentes, M., 
Geer, A. J., Haimberger, L., Healy, S. B., Hersbach, H., Hólm, E. V., Isaksen, L., Kållberg, P., Köhler, M., Matricardi, M., McNally, A. P., Monge-Sanz, B. M., Morcrette, J.-J., Park, B.K., Peubey, C., de Rosnay, P., Tavolato, C., Thépaut, J.-N., and Vitart, F.: The ERA-Interim reanalysis: configuration and performance of the data assimilation system, Q. J. Roy. Meteor. Soc., 137, 553-597, 2011.

de Koeijer, G., Talstad, V. R., Nepstad, S., Tønnesen, D., FalkPedersen, O., Maree, Y., and Nielsen, C.: Health risk analysis of emissions to air from $\mathrm{CO}_{2}$ Technology Center Mongstad, Int. J. Greenh. Gas Con., 18, 200-207, 2013.

Drewes, J. E., Hoppe, C., and Jennings, T.: Fate and transport of n-nitrosamines under conditions simulating full-scale groundwater recharge operations, Water Environ. Res., 78, 2466-2473, doi:10.2175/106143006x115408, 2006.

Fagerli, H. and Aas, W.: Trends of nitrogen in air and precipitation: model results and observations at EMEP sites in Europe, 19802003, Environ. Pollut., 154, 448-461, 2008.

Fisher, B. E. A., Erbrink, J. J., Finardi, S., Jeannet, P., Joffre, S., Morselli, M. G., Pechinger, U., Seibert, P., and Thomson, D. J.: COST Action 710 - Final report, Harmonisation of the preprocessing of meteorological data for atmospheric dispersion models, EUR 18195, Office for Official Publications of the European Communities, Luxembourg, 431, 1998.

Ge, X., Wexler, A. S., and Clegg, S. L.: Atmospheric amines - Part 2: Thermodynamic properties and gas/particle partitioning, Atmos. Environ., 45, 561-577, 2011.

Goff, G. S. and Rochelle, G. T.: Monoethanolamine degradation: $\mathrm{O}_{2}$ mass transfer effects under $\mathrm{CO}_{2}$ capture conditions, Ind. Eng. Chem. Res., 43, 6400-6408, 2004.

Hanna, S. R., Briggs, G. A., and Hosker Jr., R. P.: Handbook on Atmospheric Diffusion, edited by: Smith, J. S., DOE/TIC-11223, Technical Information Center, US Department of Energy, Springfield, USA, 1982

Högström, U.: Review of some basic characteristics of the atmospheric surface layer, Bound.-Lay. Meteorol., 78, 215-246, 1996.

Holmes, N. S. and Morawska, L.: A review of dispersion modelling and its application to the dispersion of particles: an overview of different dispersion models available, Atmos. Environ., 40, 5902-5928, 2006.

Hurley, P., Physick, W., and Luhar, A.: TAPM - a practical approach to prognostic meteorological and air pollution modelling, Environ. Modell. Softw., 20, 737-752, doi:10.1016/j.envsoft.2004.04.006, 2005.

Hutchings, J. W., Ervens, B., Straub, D., and Herckes, P. N.: Nitrosodimethylamine occurrence, formation, and cycling in clouds and fogs, Environ. Sci. Technol., 41, 393-399, 2010.

IPCC: Intergovernmental Panel on Climate Change (IPCC) Special Report on Carbon Dioxide Capture and Storage, Cambridge University Press, Cambridge, UK, 2005.

Jonson, J. E., Simpson, D., Fagerli, H., and Solberg, S.: Can we explain the trends in European ozone levels?, Atmos. Chem. Phys., 6, 51-66, doi:10.5194/acp-6-51-2006, 2006.

Kaplan, D. L. and Kaplan, A. M.: Biodegradation of nnitrosodimethylamine in aqueous and soil systems, Appl. Environ. Microb., 50, 1077-1086, 1985.

Karl, M., Wright, R. F., Berglen, T. F., and Denby, B.: Worst case scenario study to assess the environmental impact of amine emis- sions from a $\mathrm{CO}_{2}$ capture plant, Int. J. Greenh. Gas Con., 5, 439447, 2011.

Karl, M., Dye, C., Schmidbauer, N., Wisthaler, A., Mikoviny, T., D’Anna, B., Müller, M., Borrás, E., Clemente, E., Muñoz, A., Porras, R., Ródenas, M., Vázquez, M., and Brauers, T.: Study of $\mathrm{OH}$-initiated degradation of 2-aminoethanol, Atmos. Chem. Phys., 12, 1881-1901, doi:10.5194/acp-12-1881-2012, 2012.

Karl, M., Svendby, T., Walker, S.-E., Velken, A. V. S., Castell, N., and Solberg, S.: Modelling atmospheric oxidation of 2aminoethanol (MEA) emitted from post-combustion capture using WRF-Chem, Sci. Total Environ., in preparation, 2014.

Kuenen, J., Denier van der Gon, H., Visschedijk, A., and van der Brugh, H.: High resolution European emission inventory for the years 2003-2007, TNO report TNO-060-UT-2011-00588, Utrecht, the Netherlands, 2011.

Låg, M., Lindeman, B., Instanes, C., Brunborg, G., and Schwarze, P.: Health effects of amines and derivatives associated with $\mathrm{CO}_{2}$ capture, Norwegian Institute of Public Health, available at: http://www.fhi.no/dokumenter/ca838717be.pdf (last access: 29 June 2014), 2011.

Lazarou, Y. G., Kambanis, K. G., and Papagiannakopoulos, P.: Gas phase reactions of $\left(\mathrm{CH}_{3}\right)_{2} \mathrm{~N}$ radicals with $\mathrm{NO}$ and $\mathrm{NO}_{2}$, J. Phys. Chem., 98, 2110-2115, 1994.

Lee, D. and Wexler, A. S.: Atmospheric amines - Part 3: Photochemistry and toxicity, Atmos. Environ., 71, 95-103, doi:10.1016/j.atmosenv.2013.01.058, 2013.

Mackay, D.: Multimedia Environmental Models: the Fugacity Approach, 2nd Edn., CRC press, Boca Raton, FL, 2001.

Mackay, D., Di Guardo, A., Paterson, S., Kicsi, G., and Cowan, C. E.: Assessing the fate of new and existing chemicals: a five-stage process, Environ. Toxicol. Chem., 15, 1618-1626, 1996.

MacLeod, M. and Mackay, D.: An assessment of the environmental fate and exposure of benzene and the chlorobenzenes in Canada, Chemosphere, 38, 1777-1796, 1999.

MacLeod, M., Fraser, A. J., and Mackay, D.: Evaluating and expressing the propagation of uncertainty in chemical fate and bioaccumulation models, Environ. Toxicol. Chem., 21, 700-709, 2002.

Malloy, Q. G. J., Li Qi, Warren, B., Cocker III, D. R., Erupe, M. E., and Silva, P. J.: Secondary organic aerosol formation from primary aliphatic amines with $\mathrm{NO}_{3}$ radical, Atmos. Chem. Phys., 9, 2051-2060, doi:10.5194/acp-9-2051-2009, 2009.

Nielsen, C. J., D’Anna, B., Dye, C., Graus, M., Karl, M., King, S., Musabila, M., Müller, M., Schmidbauer, N., Stenstrøm, Y., Wisthaler, A., and Pedersen, S.: Atmospheric chemistry of 2aminoethanol (MEA), Energy Procedia, 4, 2245-2252, 2011.

Nielsen, C. J., D’Anna, B., Bossi, R., Bunkan, A. J. C., Dithmer, L., Glasius, M., Hallquist, M., Hansen, A. M. K., Lutz, A., Salo, K., Maguta, M. M., Nguyen, Q., Mikoviny, T., Müller, M., Skov, H., Sarrasin, E., Stenstrøm, Y., Tang, Y., Westerlund, J., and Wisthaler, A.: Atmospheric Degradation of Amines (ADA): summary report from atmospheric chemistry studies of amines, nitrosamines, nitramines and amides, University of Oslo, Oslo, 2012a.

Nielsen, C. J., Herrmann, H., and Weller, C.: Atmospheric chemistry and environmental impact of the use of amines in carbon capture and storage (CCS), Chem. Soc. Rev., 41, 6684-6704, $2012 b$. 
Norwegian Climate and Pollution Agency: Permit for Activities Pursuant to the Pollution Control Act for $\mathrm{CO}_{2}$ Technology Centre Mongstad DA, available at: http://www.tcmda.com/Global/ Dokumenter/Klif_TCM_Discharge\%20permit.pdf (last access: 29 June 2014), 2011.

Onel, L., Blitz, M. A., and Seakins, P. W.: Direct determination of the rate coefficient for the reaction of $\mathrm{OH}$ radicals with monoethanol amine (MEA) from 296 to $510 \mathrm{~K}$, J. Phys. Chem. Lett. 3, 853-856, 2012.

Owen, B., Edmunds, H. A., Carruthers, D. J., and Singles, R. J.: Prediction of total oxides of nitrogen and nitrogen dioxide concentrations in a large urban area using a new generation urban scale dispersion model with integral chemistry model, Atmos. Environ., 34, 397-406, 2000.

Pitts, J. N., Grosjean, D., Vanmcauwenberghe, K., Schmidt, J. P., and Fitz, D. R.: Photooxidation of aliphatic amines under simulated atmospheric conditions: formation of nitrosamines, nitramines, amides, and photochemical oxidant, Environ. Sci. Technol., 12, 946-953, 1978.

Plumlee, M. H. and Reinhard, M.: Photochemical attenuation of nnitrosodimethylamine (NDMA) and other nitrosamines in surface water, Environ. Sci. Technol., 41, 6170-6176, 2007.

Price, D. J.: Field and Smog Chamber Studies of Agricultural Emissions and Reaction Products, Master's thesis, All Graduate Theses and Dissertations, Paper 592, Utah State University, available at: http://digitalcommons.usu.edu/etd/592 (last access: 10 December 2013), 2010.

Rao, A. B. and Rubin, E. S.: A technical, economic, and environmental assessment of amine-based $\mathrm{CO}_{2}$ capture technology for power plant greenhouse gas control, Environ. Sci. Technol., 36, 4467-4475, 2002.

Reynolds, A. J., Verheyen, T. V., Adeloju, S. B., Meuleman, E., and Feron, P.: Towards commercial scale postcombustion capture of $\mathrm{CO}_{2}$ with monoethanolamine solvent: key considerations for solvent management and environmental impacts, Environ. Sci. Technol., 46, 3643-3654, 2012.

Richardson, S. D., Plewa, M. J., Wagner, E. D., Schoeny, R., and DeMarini, D. M.: Occurrence, genotoxicity, and carcinogenicity of regulated and emerging disinfection by-products in drinking water: a review and roadmap for research, Mutat. Res.-Rev. Mutat, 636, 178-242, doi:10.1016/j.mrrev.2007.09.001, 2007.

Rochelle, G. T.: Amine scrubbing for $\mathrm{CO}_{2}$ capture, Science, 325, 1652-1653, 2009.

Salo, K., Westerlund, J., Andersson, P. U., Nielsen, C. J., D'Anna, B., and Hallquist, M.: Thermal characterization of alkyl aminium nitrate nanoparticles, J. Phys. Chem. A, 115, 1167111677, 2011.

Saloranta, T. M., Armitage, J. M., Haario, H., Næs, K., Cousins, I. T., and Barton, D. N.: Modeling the effects and uncertainties of contaminated sediment remediation scenarios in a Norwegian Fjord by Markov chain Monte Carlo simulation, Environ. Sci. Technol., 42, 200-206, 2007.

Simpson, D., Fagerli, H., Hellsten, S., Knulst, J. C., and Westling, O.: Comparison of modelled and monitored deposition fluxes of sulphur and nitrogen to ICP-forest sites in Europe, Biogeosciences, 3, 337-355, doi:10.5194/bg-3-337-2006, 2006a.

Simpson, D., Butterbach-Bahl, K., Fagerli, H., Kesik, M., Skiba, U., and Tang, S.: Deposition and emissions of reactive nitrogen over
European forests: a modelling study, Atmos. Environ., 40, 57125726, 2006b.

Simpson, D., Benedictow, A., Berge, H., Bergström, R., Emberson, L. D., Fagerli, H., Flechard, C. R., Hayman, G. D., Gauss, M., Jonson, J. E., Jenkin, M. E., Nyíri, A., Richter, C., Semeena, V. S., Tsyro, S., Tuovinen, J.-P., Valdebenito, Á., and Wind, P.: The EMEP MSC-W chemical transport model - technical description, Atmos. Chem. Phys., 12, 7825-7865, doi:10.5194/acp-127825-2012, 2012.

Skamarock, W. C. and Klemp, J. B.: A time-split nonhydrostatic atmospheric model for weather research and forecasting applications, J. Comput. Phys., 227, 3465-3485, doi:10.1016/j.jcp.2007.01.037, 2008.

Skamarock, W. C., Klemp, J. B., Dudhia, J., Gill, D. O., Barker, D. M., Duda, M. G., Huang, X.-Y., Wang, W., and Powers, J. G.: A Description of the Advanced Research WRF Version 3, NCAR Technical note, NCAR/TN-475+STR, available at: http://www.mmm.ucar.edu/wrf/users/docs/arw_v3.pdf (last access: 29 June 2014), 2008.

Solberg, S. and Svendby, T.: Development of a nested WRF/EMEP modelling system at NILU, in: Transboundary acidification, eutrophication and ground level ozone in Europe in 2010, edited by: Fagerli, H., Gauss, M., Benedictow, A., Jonson, J. E., Nyíri, A., Schulz, M., Simpson, D., Steensen, B. M., Tsyro, S., Valdebenito, A., Wind, P., Shamsudheen, S. V., Aas, W., Hjelbrekke, A.G., Mareckova, K., Wankmuller, R., Solberg, S., Svendby, T., Vieno, M., Thunis, P., Cuvelier, K., Koffi, B., and Bergtström, R., Norwegian Meteorological Institute - MSC-W (EMEP status report 1/2012), Oslo, 81-89, 2012.

Strazisar, B. R., Anderson, R. R., and White, C. M.: Degradation pathways of monoethanolamine in a $\mathrm{CO}_{2}$ capture facility, Energ. Fuel., 17, 1034-1039, 2003.

Tang, Y., Hanrath, M., and Nielsen, C. J.: Do primary nitrosamines form and exist in the gas phase? A computational study of $\mathrm{CH}_{3} \mathrm{NHNO}$ and $\left(\mathrm{CH}_{3}\right)_{2} \mathrm{NNO}$, Phys. Chem. Chem. Phys., 14, 16365-16370, 2012.

Tønnesen, D., Dye, C., and Bøhler, T.: Baseline study on air and precipitation quality for $\mathrm{CO}_{2}$ Technology Centre Mongstad, Norwegian Institute for Air Research, NILU OR 73/2011, Kjeller, Norway, 2011.

US EPA: Estimation Programs Interface Suite for Microsoft Windows, v 4.00, United States Environmental Protection Agency, Washington, DC, USA, available at: http://www.epa. gov/opptintr/exposure/pubs/episuite.htm (last access: 29 June 2014), 2012.

Verwer, J. and Simpson, D.: Explicit methods for stiff ODEs from atmospheric chemistry, Appl. Numer. Math., 18, 413-430, 1995.

Verwer, J. G., Blom, J. G., and Hundsdorfer, W.: An implicit explicit approach for atmospheric transport-chemistry problems, Appl. Numer. Math., 20, 191-209, 1996.

Vieno, M., Dore, A. J., Wind, P., Di Marco, C., Nemitz, E., Phillips, G., Tarrason, L., and Sutton, M. A.: Application of the EMEP Unified Model to the UK with a Horizontal Resolution of $5 \times 5 \mathrm{~km}^{2}$, in: Atmospheric Ammonia - Detecting Emission Changes and Environmental Impacts, edited by: Sutton, M. A., Reid, S., and Baker, S. M. H., Springer, Berlin, Heidelberg, Germany, 367-372, 2009.

Vieno, M., Dore, A. J., Stevenson, D. S., Doherty, R., Heal, M. R., Reis, S., Hallsworth, S., Tarrason, L., Wind, P., Fowler, D., Simp- 
son, D., and Sutton, M. A.: Modelling surface ozone during the 2003 heat-wave in the UK, Atmos. Chem. Phys., 10, 7963-7978, doi:10.5194/acp-10-7963-2010, 2010.

Wieringa, J.: Updating the Davenport roughness classification, J. Wind Eng. Ind. Aerod., 41-44, 357-368, 1992.

Wolke, R., Knoth, O., Hellmuth, O., Schroder, W., and Renner, E.: The parallel model system LM/MUSCAT for chemistry transport simulations: coupling scheme, parallelization and applications, Adv. Par. Com., 13, 363-369, 2004.
Yang, W. C., Gan, J., Liu, W. P., and Green, R.: Degradation of n-nitrosodimethylamine (NDMA) in landscape soils, J. Environ. Qual., 34, 336-341, 2005.

Zhou, Q. L., McCraven, S., Garcia, J., Gasca, M., Johnson, T. A., and Motzer, W. E.: Field evidence of biodegradation of nnitrosodimethylamine (NDMA) in groundwater with incidental and active recycled water recharge, Water Res., 43, 793-805, doi:10.1016/j.watres.2008.11.011, 2009. 